Jordinndelingene i Finnmark: var de Norges eldste offentlige utskiftinger?

Vitenskapelig publikasjon

\title{
Jordinndelingene i Finnmark: var de Norges eldste offentlige utskiftinger?
}

\section{The property divisions in Finnmark: were they Norway's} oldest public land consolidations?

\section{Øyvind Ravna, professor dr.juris, UiT Norges arktiske universitet oyvind.ravna@uit.no}

Den har vært antatt at det i Finnmark i eldre tid ikke eksisterte jordfellesskap eller teigblanding, da all jord tilhørte staten eller Kongen. Dermed var det heller ikke behov for utskiftning. Finnmark ble eksempelvis utelatt da Utskiftningsvæsenet ble opprettet i Norge i 1859, samtidig som historien forteller at den første utskiftningsformannen ble tilsatt i Finnmark i 1938. Det finnes imidlertid en annen historie. Den forteller at det eksisterte jordfellesskap og ugreie jordforhold på 1700-tallet, og at de første utskiftingene utført av en kongelig beskikket landmåler i Finnmark, fant sted i 1776.

It has been assumed that in Finnmark in earlier times there was no land community or complex property conditions, as all the land belonged to the state or the King. Thus, there was no need for land consolidation or severance. The county of Finnmark, for example, was left out when the Land Consolidation Service was established in Norway in 1859, while the history tells that the first Land Consolidation officer for Finnmark was appointed in 1938. However, there is another story. It tells that there was a land community and difficult property conditions in the 18th century and that the first land severance carried out by a royally appointed surveyor took place in Finnmark in 1776.

Key words: land consolidation, property division, legal history, severance

\section{Innledning ${ }^{1}$}

\subsection{Problemstilling}

Eiendomshistorien i Norge forteller ikke mye om Finnmark. Det har imidlertid vært en allmenn oppfatning, slik det uttrykkes i forarbeidene til vår forrige finnmarkslov, at «[s]å langt tilbake som den norske soge vet å berette, var all jord og grunn i det egentlige Finnmark betraktet som statens eiendom». Det het også at private eiendommer oppsto først ved en resolusjon i 1775 som «bestemte at jord - boplasser - [75] kunne utvises til full eiendom. Utvisningen var

\footnotetext{
${ }^{1}$ Takk til statsarkivarene Yngve Nedrebø og Harald Lindbach for transkribering og bistand til dokuments $\varnothing \mathrm{k}$, samt til advokat Brynjar Østgård for anledning til å bistå han i Nesseby- og Gulgofjordsaken, noe som avdekket behov for studier av eiendomshistorien til Finnmark. Takk også til to anonyme fagfeller for nyttige merknader. 
Jordinndelingene i Finnmark: var de Norges eldste offentlige utskiftinger?

gratis». ${ }^{2}$ Oppfatningen var altså at det verken eksisterte jordfellesskap eller andre former for private eiendommer lengst nord i riket på den tiden da Danmark-Norge for alvor fikk øynene opp for jordfellesskapets ulemper for jordbruket andre steder i fellesriket. Det var således ikke grunn til å ta med Finnmark da Norge fikk sin første utskiftningslov i 1821, eller sine første offentlig ansatte utskiftningsmenn i 1859.

I en studie publisert i Tidsskrift for Rettsvitenskap har jeg kommet til at jordstrekningene langs fjordene og elvedalene i Finnmark neppe var statens eiendom, men jordfellesskap mellom oppsitterne der. ${ }^{3}$ En del av denne studien viser også at nevnte resolusjon ikke initierte jordoverdragelse, men det som best kan karakteriseres som deling av jordfellesskap, noe dens tittel også peker på. ${ }^{4}$ Til oppgaven ble det beskikket to landmålere hvor den ene lyktes i slik grad at han hadde inndelt fellesskapet i 689 eiendommer i året 1789.

Problemstillingen for denne studien er å unders $\varnothing \mathrm{ke}$ om jordinndelingene som fant sted $\mathrm{i}$ Finnmark fra 1776 og de etterfølgende fire tiårene, kan anses som utskiftinger - og dermed være av de eldste i Norge i offentlig regi. ${ }^{5}$ Av plasshensyn er undersøkelsen avgrenset til 1815.

\subsection{Oppfatning om utskifting i Finnmark, kilder og metode}

Utskiftingshistorien for Finnmark er i dag svært kort og kan vel mer korrekt omtales som

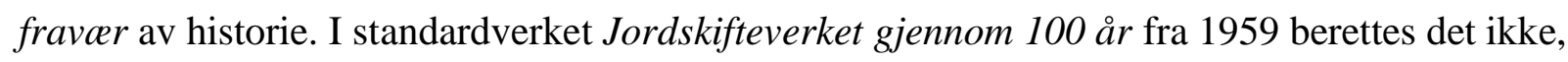
i motsetning til for det $\varnothing$ vrige Kyst-Norge, om utskiftinger før 2. verdenskrig.

Utskiftingshistorien i Finnmark starter med en anførsel bak i boka om at det ble tilsatt en utskiftingsformann i fylket $1938 .{ }^{6}$ Heller ikke i Eigedomshistorie - Hovudliner i norsk eigedomshistorie frå 1600-talet fram mot nåtida fortelles det om jordfellesskap lengst nord i landet - og følgelig heller ikke om utskiftinger før i 1938. ${ }^{7}$ Den eneste påviste omtalen av eldre utskifting i Finnmark i 1900- og 2000-tallslitteraturen er noen korte avsnitt i Ola Juvkams «Træk fra utskifningsvæsenets historie» fra $1917 .{ }^{8}$ I tillegg [76] har Sverre Tønnesen pekt på at

\footnotetext{
${ }^{2}$ Innstilling om lov og forskrifter om statens umatrikulerte grunn i Finnmark fylke, 1962, s. 5 og 7. Med det egentlige Finnmark siktes det Norges nordligste amt eller fylke, slik det var definert før 1787 (uten Troms $\varnothing$ og Senjen fogderi), og slik det var fra 1866 fram til 1. januar 2020.

${ }^{3}$ Øyvind Ravna, «Den tidligere umatrikulerte grunnen i Finnmark: Jordfellesskap fremfor statlig eiendom?», Tidsskrift for Rettsvitenskap nr. 2-3/2020, s. 219-263, www.idunn.no/tfr/2020/02-03/den tidligere umatrikulerte grunnen i finnmark jordfelless

${ }^{4}$ Kongelig Resolution 27. mai 1775 ang. Jorddelingen i Finmarken samt Bopladses Udvisning og Skyldlægning sammesteds, jf. https://lovdata.no/dokument/NL/lov/1775-05-27 (02.01.21). Resolusjonens rette dato er 8. juni 1775, jf. note 44 nedenfor.

${ }^{5}$ Med offentlig utskifting eller regi menes forretninger utført av offentlige tjeneste- eller embedsmenn.

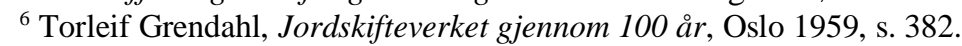

${ }^{7}$ Hans Sevatdal, v/Per Kåre Sky og Erling Berge, Eigedomshistorie. Hovudliner i norsk eigedomshistorie frå 1600-talet fram mot nåtida, Oslo 2017.

${ }^{8}$ O. Juvkam, «Træk fra utskifningsvæsenets historie», Tidsskrift for Det norske Udskiftningsvaesen, 1917, s. 41-161. Dette er imidlertid utelatt i en fremstilling av Juvkam over temaet drøyt 30 år senere: O. Juvkam, «Utstykking og skyldsetting i Finnmark», Tidsskrift for Det norske Utskiftningsvesen, 1948, s. 127-141.
} 
Jordinndelingene i Finnmark: var de Norges eldste offentlige utskiftinger?

1775-resolusjonen kunne sikte mot «en gigantisk utskiftning mellom Kongen, den enkelte bygdemann og bygdelagene». ${ }^{9}$ Tønnesen konkretiserer imidlertid ikke dette, og slipper dermed en viktig tråd i sitt avhandlingsarbeid.

Manglende omtale og drøfting i nyere litteratur betyr ikke at det ikke finnes dokumentasjon på tidlige jorddelinger og utskiftingsartede forretninger i Finnmark; de finnes i betydelig omfang fra 1776 og fram til midten av 1800-tallet. Det kan også vises til at behovet for utskifting i Finnmark er omtalt så tidlig som i 1745, og at det endatil ble foreslått en egen lov om Jords Udskiftning af Fallesskap for Finnmark i 1826. ${ }^{10}$

På samme måte som nevnte studie av eiendomshistorien, ${ }^{11}$ som denne studien bygger på, vil denne ha en rettshistorisk tilnærming, hvor det tas et utgangspunkt i datidens dansk-norske landbrukspolitikk, rettsoppfatninger og forvaltningspraksis. 1775-resolusjonen og dens forarbeider vil naturlig være sentrale, samtidig som skjøter og beskrivelser av jordinndelingsforretninger i pantebøker og landmålerprotokoller vies en oppmerksomhet de ikke tidligere har fått. Med bakgrunn i dette nyttes de eldre kildene med blikk på om de bidrar til å belyse utskiftingshistorien og dermed studiens problemstilling.

\subsection{Om jordfellesskap, utskifting, eiendom og allmenning}

Før det gås inn på om jorddelingen i Finnmark kan betegnes som utskifting, er det nyttig å se på noen begreper, herunder hvordan eiendom ble oppfattet i den dansk-norske enevoldstiden. Den gang var det vanlig at bygdejorda lå i forskjellige former for fellesskap, mens den fjernere utmarka kunne være allmenning hvor bygdefolk hadde bestemte bruksrettigheter. ${ }^{12}$ Dette var tilfellet langs Kyst-Norge, fra Vestlandet og nordover. ${ }^{13}$ Fellesskapet eller jordsameiet har i stor grad vært gjenstand for utskifting, ${ }^{14}$ noe som innebar at det ble oppløst og at sameiedelene ble utlagt til eiendommer i eneeie. ${ }^{15}$ I dag er [77] slikt sameie, som oftest omfatter utmark, knyttet til en innmarkseiendom. I eldre tid kunne all jord i bygda, også innmarka, ligge i

\footnotetext{
${ }^{9}$ Sverre Tønnesen, Retten til jorden i Finnmark. [... ]», Bergen 1972, s. 146.

${ }^{10}$ Udkast til en Lov om de Staten i Finmarken tilhørende Jorders Inddeling til Boeplads, og om Jords Udskiftning af Fælledsskab, 25. november 1826, se Riksarkivet/EA-4036 Utenriksarkivet, serie H - A. Ræstads samlinger, underserie $\mathrm{Hb}$, eske 18: Kommisjonen til Finmarkens oppkomst. Jf. også Vilhelm Haffner, Innstillinger og betenkninger fra kongelige og parlamentariske kommisjoner [...] m.m. 1814-1924, Oslo 1925, s. 53. Om forslaget i 1745, se note 41 og 42 nedenfor.

${ }^{11}$ Se note 3 ovenfor.

${ }^{12}$ Tønnesen (1972), s. 11, og K. Meinich Olsen, Norsk almenningsret, Oslo 1928, s. 220. Se også Knut Robberstad, «Kløyvd eiendomsrett», Lov og Rett 1963, s. 162-166.

${ }^{13}$ Mads Langnes, «Det fordervelege jordfellesskapet», Heimen 4/2019, s. 279-295, hvor grunnen til fellesskapet drøftes.

${ }^{14}$ Fra lov 22. des. 1950 om jordskifte o.a. betegnet som jordskifte, som etter $§ 2$ omfattet oppløsning av sameie og teigblanding. Teigblanding falt inn under begrepet «jordfellesskap», gjerne som «ufullkomment jordfellesskap».

15 Omtalt som utlodding i lov 12. okt. 1857 om Jords og Skovs Udskiftning § 13 m.fl. I forordning (lov) 23 April 1781 om Jord-Fælledsskabets Ophævelse [...] i Danmark §§ 4, 7 og 27 nyttes på tilsv. måte begrepene «tildel[ing]», «Inddelingen» og «Uddeling», se Jacob Henric Schou, Chronologisk Register over de Kongelige Forordninger og Aabne Breve, som fra Aar 1670 af ere udkomne, VIII Deel, fra 1781 til 1784, Kiøbenhavn 1795, s. 96-133.
} 
Jordinndelingene i Finnmark: var de Norges eldste offentlige utskiftinger?

sameie. Etter hvert ble fellesskapet delt inn i gårder og eiendommer, ${ }^{16}$ hvor eiendom ble sett på som motstykket til fellesskap. ${ }^{17}$ Eiendommer har dermed oppstått ved utskifting. For $\emptyset$ vrig har eiendommer blitt til uavhengig av statlige akter - ved originære erverv (landnåm), sedvane eller alders tids bruk.

I et rettshistorisk arbeid må det tas hensyn til at eiendomsbegrepet i den dansk-norske enevoldstiden var forankret i oppfatninger fra middelalderens føydal- eller lensvesen, hvor kongen (eller jorddrotten) hadde overeiendomsrett, en «høyhetsrett» (dominium directum), og bonden en undereiendomsrett, som var av privatrettslig art (dominium utile). ${ }^{18}$ Kongen ble $\mathrm{i}$ medhold av overeiendomsretten ansett som allmenningseier, med rett til å «bortbygge nogen Plads i Almindingen» til rydning, og å ta «Leje og Leding» når gården var ryddet. ${ }^{19}$

Oppfatningen om en lagdelt eiendomsrett levde ennå på 1800-tallet. Fr. Brandt skriver at «Staten tilkommer, som representant for Menneskesamfunnet i det Hele, det principale Herredømme over alle Ting inden dens Grænser. Denne saakaldte Overejendomsret er saaledes ikke nogen Indskrænkning i, men tvertimod Forudsætningen for den private Ejendomsrett». ${ }^{20}$

Brækhus og Hærem anfører at overeiendomsretten med naturrettens tankegang utviklet seg til «nærmest en betegnelse for statens almindelige suverenitet, dens myndighet til å pålegge skatter og til å gjøre andre inngrep i eiendomsretten, f.eks. ved å gi lover». Men ordets makt var stor, fortsetter Brækhus og Hærem, «og det var ikke lett å frigjøre seg fra den forestilling at 'overeiendomsrett' hadde noe med eiendomsrett å gjøre». ${ }^{21}$ Brækhus og Hærem skriver også, med henvisning til Asm. Schiefloe, at statens overeiendomsrett har hatt størst betydning for allmenningsretten. ${ }^{22}$ Schiefloe konkluderte etter en drøfting av dansk lovgivning og praksis med at «den rett kongemakten i det 17. og 18. århundre hadde, ikke var noen eiendomsrett, men alene en beskatningsrett $\mathrm{i}$ henhold til den dagjeldende statsrettslige doktrinen». ${ }^{23}$

\footnotetext{
${ }^{16}$ Paul Borgedal, «Jordeiendommenes historie i Norge», i Torleif Grendahl (red.), Jordskifteverket gjennom 100 år 1859-1958, Oslo 1959, s. 135-166 (s. 20-22).

${ }^{17}$ Hans Paus, Naturens Ret, som en Grundvold til Den Danske og Norske Borgerlige Rett, Anden part, Kjøbenhavn 1750, s. 174.

${ }^{18}$ Paus (1750), s. 174 og 180-181. Se også Herman Scheel, Forelasninger over norsk Tingsret, Kristiania 1912, s. 145; Gudmund Sandvik, «Europeisk rettshistorie i mellomalderen», Jussens Venner, 6-7/1989, s. 201-309; og Finnmarkskommisjonen, Rapport Felt 4 Karasjok, bind 1, 2019, s. 36.

${ }^{19}$ Kong Christian den 5.s Norske Lov 15. april 1687 (NL) 3-12-4 og 3-12-8.

${ }^{20}$ Fr. Brandt, Tingsretten, fremstillet efter den norske Lovgivning, Kristiania 1867, s. 78 (uthevet av Brandt), som også skriver at overeiendomsretten har to anvendelser: Det er beskatningsretten og ekspropriasjonsretten.

${ }^{21}$ Sjur Brækhus og Axel Hærem, Norsk tingsrett, Oslo 1964, s. 526, med henv. til Brandt (sitert ovenfor).

${ }^{22}$ Brækhus og Hærem (1964), s. 526, med henv. til Asm. Schiefloe, Hovedlinjer i Norsk almenningsrett, Oslo 1955.

${ }^{23}$ Schiefloe (1955), s. 135. Han viser også at ved 1814-forfatningen bortfalt høyhetsretten til Kongen (av Danmark), hvoretter han etterlyser en «ny hjemmel enten for fremdeles å hevde den gamle overeiendomsretten eller endog utvide den til en mer vidtgående rett, en virkelig eiendomsrett» (s. 138).
} 
Jordinndelingene i Finnmark: var de Norges eldste offentlige utskiftinger?

For øvrig var ikke vern mot inngrep i eiendom en del av enevoldstidens rett, noe som innebar at kongemakten nokså fritt kunne gjøre inngrep i rettigheter av privatrettslig art. ${ }^{24}$

\section{Kgl. Resolution ang. Jordbrugets Inddeling til visse Boepladser i Finmarken}

\subsection{Den danske landboreformen}

På midten av 1700-tallet, med opplysningstidens framvekst, fikk myndighetene i DanmarkNorge forståelse for jordfellesskapets hindring for et effektivt jordbruk. Det ble da et annet fokus på en rettstradisjon som skrev seg tilbake til middelalderen. ${ }^{25}$ I 1757 ble det nedsatt en kommisjon som skulle forberede en lov om oppløsning av jordfellesskap i Danmark, og i årene 1758-1761 kom det flere forordninger om utskifting av allmenningene. ${ }^{26}$

Jordfellesskapet, som etter hvert ble sett på som det største hinderet for et effektivt jordbruk, ledet til ytterligere forordninger, før Danmark i 1781 fikk en egen utskiftningslov. ${ }^{27}$ Den bestemte at når én loddeier forlangte sin jord utskiftet, skulle landsbyens jorder oppmåles og fordeles, hvor loddeierne var pliktige til å delta i grøfte- og gjerdearbeid m.m. Loven må ses i sammenheng med reformene for å avvikle leilendingsvesenet, idet myndighetene stilte krav om utskifting før salg av leilendingsbruk til selveie kunne finne sted. Samtidig bidro utskiftingene til å øke utbyttet i slik grad at leilendingene fikk økonomi til å kjøpe seg fri fra godseierne. ${ }^{28}$

I en innstilling fra 1792 het det at av alle ordninger for å bedre bondestandens kår «fører ingen hurtigere og vissere til det rigtige Maal end Udskiftningen av Fællesskab». ${ }^{29}$ Innen 1810, i det som omtales som landboreformen, var utskiftingen av den danske landsbygda stort sett fullført, samtidig som det årlige jordbruksutbyttet omtrent var fordoblet sammenliknet med $1788 .{ }^{30}$

\subsection{Forarbeidene til resolusjonen}

Finnmark var langt unna København. Med også her ønsket myndighetene å bedre kårene for jordbruket. På oppdrag fra amtmann Eiler Hagerup (1768-1771) skrev Hans Paus, som etter

\footnotetext{
${ }^{24}$ Finnmarkskommisjonen (2019), s. 32, og Håvard Steinsholt, «Oreigning», i Hans Sevatdal, v/Per Kåre Sky og Erling Berge, Eigedomshistorie. Hovudliner i norsk eigedomshistorie frå 1600-talet fram mot nåtida, Oslo 2017, s. 379-381.

${ }^{25}$ I Norge hadde landslova av 1274 regler om utskifting, se Borgedal (1959), s. 135. På 1700-tallet kunne utskifting i Norge utføres i medhold av NL 3-12-15.

${ }^{26}$ Borgedal (1959), s. 146.

${ }^{27}$ Forordning 23 April 1781 om Jord-Fælledsskabets Ophævelse [...]», se note 15 ovenfor. Utviklingen fram til 1781 er nærmere omtalt i Ravna (2020), s. 229.

${ }^{28}$ Danmarkshistorien, «Landboreformer i slutningen af 1700-tallet», https://danmarkshistorien.dk/leksikon-ogkilder/vis/materiale/landboreformer/ (02.01.21).

${ }^{29}$ Edvard Holm, Danmark-Norges historie fra Den Store Nordiske Krigs Slutning til Rigernes Adskillelse (1790-1814), sjette bind, anden del, Kjøbenhavn 1909, s. 418.

${ }^{30}$ Sjur Brækhus og Axel Hæren, Norsk tingsrett, Oslo 1964, s. 24, og Danmarkshistorien, «Landboreformer i slutningen af 1700-tallet». Årstallet 1788 er knyttet til forordningen av 20. juni 1788 som opphevet stavnsbånd.
} 
Jordinndelingene i Finnmark: var de Norges eldste offentlige utskiftinger?

en akademisk karriere i København ble utnevnt til sorenskriver i Finnmark i 1753, utredningen

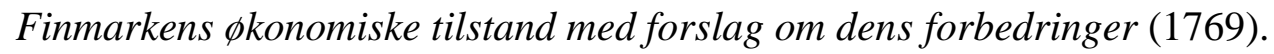

Paus’ framstilling viser at folket langs fjordene hadde sine egne «Engeslætter», og at de flyttet mellom sine sommer- og vinterboplasser. Paus beskrev også jordsameie: «Landets Fællesskab», som førte til stort misbruk av jord og skog idet sjøsamene kun nyttet sitt «Sommer-Sæde et aars Tid eller to paa et Stæd [...] som han ruinerer ruunden om sin boelig». ${ }^{31}$ Paus beskrev også teigblanding hvor to mann ofte bodde «3 a 4 Miile fra hinanden, som have et Stycke Eng ved hinandens Gamme, som om de mageskiftede kunde afslaas paa en Time og mindre». Slik situasjonen nå var, måtte enhver «slaae sit, og derpaa anvende 8 á 14 Dage, paa det begge kan ruineres». ${ }^{32}$ Paus foreslo etter dette faste sommer- og vinterbosteder, med «4 [familier] tilsammen paa et hvert Stæd. Disse 4 skulle udvises et beqemt Stæd udi i Fiordene til deres bestandige Sommer-Sæde $[\ldots] \gg .{ }^{33}$

Jordbrukets kår opptok også Thorkel Fieldsted, medlem av Det Kongelige Danske Landhusholdningsselskab og fra 1772 amtmann i Finnmark. I et skriv til Rentekammeret ${ }^{34}$ samme år uttrykker han bekymring for jordbruket i amtet på grunn av «Eiendoms Uvisshed». ${ }^{35}$ Året etter beskriver han to hovedårsaker til at jordbruket i Finnmark forsømmes. Den viktigste var «[m]angel paa ordentlig Jordinddeling og deraf følgende Uvisshed i Bruksrettigheden»:

Den Heele store Landstrækning som forstaaes under det Navn Finmarken eller Wardøehuus Amt bestaar udj een Alminding eller sadan uimmatriculeret og udeelt Land Hvor til alle Indvaanere have liige Rett, og Hvor ingen uden Kongen som Territorial Herre ejer een eneste Jordplætt. ${ }^{36}$

I denne retten, fortsetter Fieldsted, har «een hver stræbsom [...] Frihed til at optage indhegne og anvende saa meget Jord som han kan uden andres Fornermelse overkomme, og dertil gives Jordudviisning Sedler fra Amtet». Sitatet viser også at han betraktet Kongens rett som forankret i høyhetsretten.

Rentekammeret, som også var opptatt av jordbruket, ba Fieldsted om hans syn på Paus’ forslag «i Anledning af Jord-Inddeelingen». I en udatert betenkning støttet Fieldsted forslaget. Fieldsted ønsket imidlertid, i motsetning til Paus, fullt ut å avvikle jordfellesskapet:

\footnotetext{
${ }^{31}$ Hans Paus, Sorenskriver Hans Paus' Indberetning av 1769 om Finmarkens $\phi k o n o m i s k e ~ t i l s t a n d$, Vads $\varnothing 1908$ s. $12-13$.

${ }^{32}$ Paus (1769/1908) s. 13. 1 norsk mil var den gang 11,3 km., se https://snl.no/Eldre_og_fremmede_lengdeenheter

${ }^{33}$ Paus (1769/1908) s. 15-16.

${ }^{34}$ Rentekammeret hadde på 1700-tallet ansvar for staten finanser og for tilsyn og kontakter med lokal administrasjon og befolkning, se Danmarkshistorien, «Rentekammeret», https://danmarkshistorien.dk/leksikon-og-

kilder/vis/materiale/rentekammeret/ (02.01.21)

${ }^{35}$ Statsarkivet i Troms $\varnothing$ (SATØ), utskrift av kopibok nr. 6 (1772-1773) for Finmarkens amt, fol. 4 (brev til Rentekammeret, 9. aug. 1772, transkribert av A. Frøholm, SATØ, 12.04.1955).

${ }^{36}$ SATØ, utskrift av kopibok nr. 6 (1772-1773) for Finmarkens amt, fol. 103-104 (brev til Rentekammeret 28. sept. 1773, transkribert av A. Frøholm, SATØ, 25.03.1955).
} 
Jordinndelingene i Finnmark: var de Norges eldste offentlige utskiftinger?

Dersom mand skulde i Finmarken grunde Jordinddeelingen og Bopladsers Anlæg paa Grund af Fælledsskab som man paa alle vel indrettede Stæder og Provintzer søge at ophæve, saa Handlede man eftter min ringe Formeening [...] imod den Menneskelige Natur, Fælledskab i Jordbrug og tilfældige nærings Veje foraarsager intet andet end Dovenskab hos nogle Ueenighed hos andre, og Confusion hos alle. ${ }^{37}$

Det Fieldsted skrev, er svært interessant da det knytter hans forslag om jorddeling til datidens tanke om å avvikle jordfellesskap som rådet i Danmark.

I et promemoria av 31. mars 1775, som er resolusjonens mest sentrale forarbeid, utdyper Fieldsted nødvendigheten av jordinndeling:

Jeg har til forn ved adskillige Lejligheder [...] andraget, hvor nødvendig og nyttig Indrettning det vilde være for Wardøehuus Amt[fra 1787 Finmarkens amt], dersom dets Landgrunde bleve saaledes udj vise og bestemte Boepladse inddeelte, at saavel enhver Opsiddere kunde fuldkommeligen viide sine Jordbrugs Grændser og være viss paa til Ejendom for sig og sine at beholde den Plads han dyrker, optager og forbedrer, som og at nye afdeelte Rydningspladse, blev til Nybyggere indrettede. ${ }^{38}$

Et viktig argument for inndelingen var at oppsitterne kunne bli sikre på å beholde gevinsten av å forbedre jorda. At oppsitterne ikke hadde skjøte på jorda, innebar dessuten at den ikke kunne omsettes. Fieldsted mente at dette var grunnen til at få ryddet jord, og at allmuen, særlig «Finnerne», fortsatte med den utarmende flyttingen. Han foreslo derfor at det ble utarbeidet en «Plan til en Ordentlig bestemt og vedvarende Jordindeeling udi Wardøehuus Amt». Nærmere bestemt måtte det lages en plan for «Inddeeelings verket» og «afhjemle de uddeelte Jorder til de nærværende Opsiddere, samt Rydnings Pladser til Nybyggere». ${ }^{39}$ At Fieldsted så på dette som utskifting, framgår av hans betraktning om antatt tidsbruk (som han optimistisk anslo til to somre):

Der som ikke Landinddelingen havde til Øjemerke saa vel at inddeele og udmærke Rydnings Marken, som at udskiftte og sætte Grændser for de nu beboede Pladser, saa Kunde vel

Forrettningerne have hastigere Fremgang. ${ }^{40}$

\footnotetext{
${ }^{37}$ Thorkel Fieldsted, Extract Af [...] Sorenskriver Pauses Forslag i Finmarken betreffende, hvorover i Anledning af Jord-Inddeelingen udbedes (Betænkning), i Statsarkivet i Tromsø, Arkivet etter Amtmannen/Fylkesmannen i Finnmark, SAT $\varnothing / S-1120 / 1$ Afe/L1513 (transkribert av Yngve Nedrebø).

${ }^{38}$ Thorkel Fieldsted, promemoria 31.03.1775, i Riksarkivet/EA-3111 Rentekammeret, Kammerkanselliet, serie Gfd Dok. til forestillinger, pakke 22 (1772-1775), mappe: N. res. 24/1775 (8/6), Finnmark vedk. s. 1 (sidetall viser til den håndskrevne originalen).

${ }^{39}$ Fieldsted, promemoria (1775), s. 8.

${ }^{40}$ Fieldsted, promemoria (1775), s. 20 (min utheving).
} 


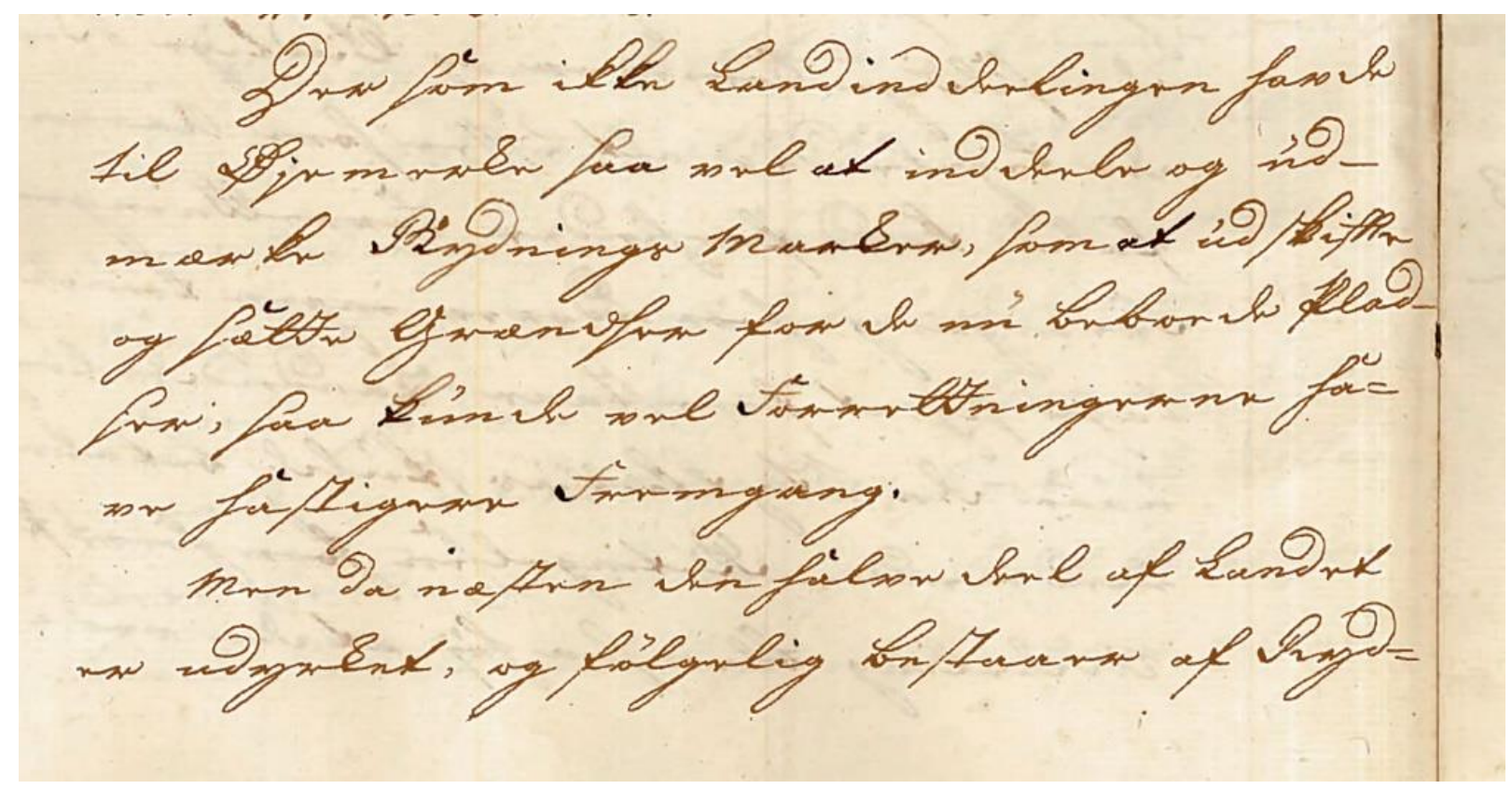

Figur 1. Utdrag fra amtmann Fieldsteds promemoria 31. mars 1775: Der som ikke Landinddelingen havde til øjemerke saa vel at inddeele og udmærke Rydnings Marken, som at udskiftte og sætte Grændser for de nu beboede Pladser, saa Kunde vel Forrettningerne have hastigere Fremgang. Hentet fra Riksarkivet/EA-3111 Rentekammeret, Kammerkanselliet, serie Gfd - Dokumenter til forestillinger, pakke 22 (1772-1775).

Fieldsted er for $\varnothing v$ vrig ikke den første som har tanker om utskifting i Finnmark. Allerede i 1745, under arbeidet med å fastlegge den norsk-svenske riksgrensen, drøftet major Schnitler å få «Jordens Brug imellem Indbyggerne, til hvers særdeles Nytte og Landets almindelige Forbedring, skifted». Dette var imidlertid «u-forgribelig: Efterdi det for de faa Kongelige Betienter ville blive for langvarigt og vidløftigt». ${ }^{41}$ For Indre Finnmark foreslo han å vente til landegrensen var fastlagt og «man da kan vide, hvad man har at skifte». ${ }^{42}$

\footnotetext{
${ }^{41}$ Peter Schnitler, Major Peter Schnitlers grenseeksaminasjonsprotokoller 1742- 1745, bind 3 ved Lars Ivar Hansen og Tom Schmidt, Norsk historisk kjeldeskrift-institutt, Oslo 1985, s. 125 (vol. 7 fol. 269).

${ }^{42}$ Schnitler (1985), s. 123.
} 


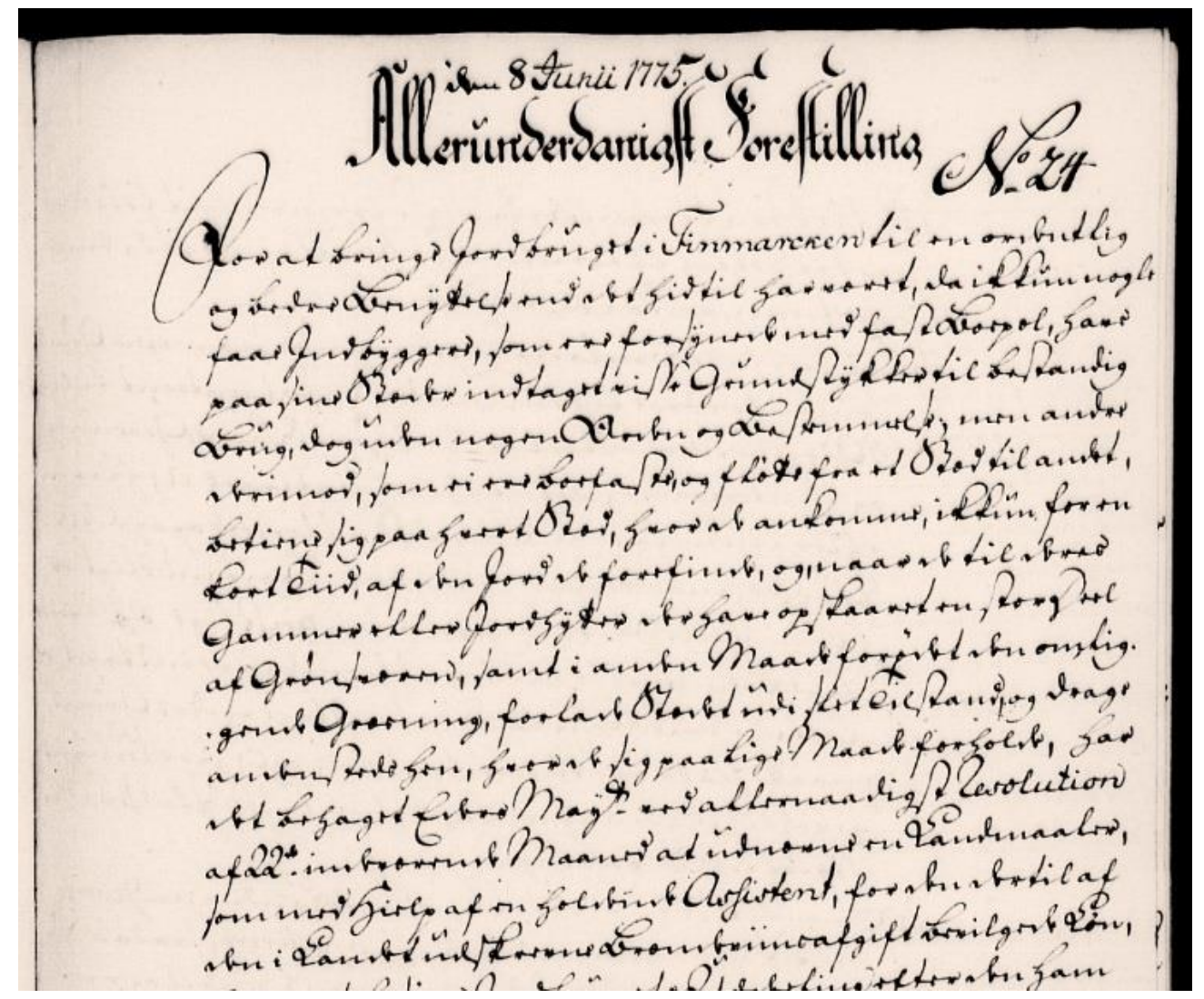

Figur 2. Allerunderdanigst forestilling no 24 utgjorde resolusjonens fortale. Den innledes slik: For at bringe Jordbruget i Finmarcken til en ordentlig og bedre Benyttelse end det hidtil har været [...] har det behaget Ærbød. Maj ${ }^{\text {st }}[\ldots .$.$] Hentet fra Riksarkivet, Rentekammeret, Kammerkanselliet, G/Gf/Gfa/L0057:$ Norsk relasjons- og resolusjonsprotokoll 1775, digitalarkivet s. 106.

\subsection{Kgl. Resolution ang. Jordbrugets Inddeling 8. juni 1775}

Fieldsteds forslag må ha falt i god jord, for allerede 27. mai s.å. la Rentekammeret fram Allerunderdanigst Forestilling $n r .24$ for kong Christian VII. ${ }^{43}$ Forestillingen, som var datidens lovproposisjon, inneholdt et utkast til resolusjon samt en fortale som viser dens formål. Det var «at bringe Jordbruget i Finmarcken til en ordentlig og bedre Benyttelse end det hidtil har været [...]». Videre var målet å avvenne innbyggerne «fra den hidtil sædvanlige og for Landet skadelige Omflakning, og derimod at tage fast Boepel, der gav dem Leilighed til bedre at anordne Jordbruget, som et Hielpemiddel til deres Underholdning, [...] hvorved og Folkeformerelsen der i Landet var at vente».

\footnotetext{
${ }^{43}$ Forestilling no. 24, Riksarkivet, Rentekammeret, Kammerkanselliet, G/Gf/Gfa/L0057: Norsk relasjons - og resolusjonsprotokoll (merket RK 52.57), 1775, s. 106, https://media.digitalarkivet.no/view/60313/106 (15.10.21).
} 
Jordinndelingene i Finnmark: var de Norges eldste offentlige utskiftinger?

Forestillingen ble approbert (vedtatt) av kong Christian VII som resolusjon 8. juni $1775,{ }^{44}$ hvor det vises til rentekammerets forslag «angaanede Jordbrugets Inddeling til visse Boepladser i Finmarken». Tittelen er interessant med tanke på resolusjonens formål. Likeledes at Rentekammerets formulering Uddeling er erstattet med Inddeling.

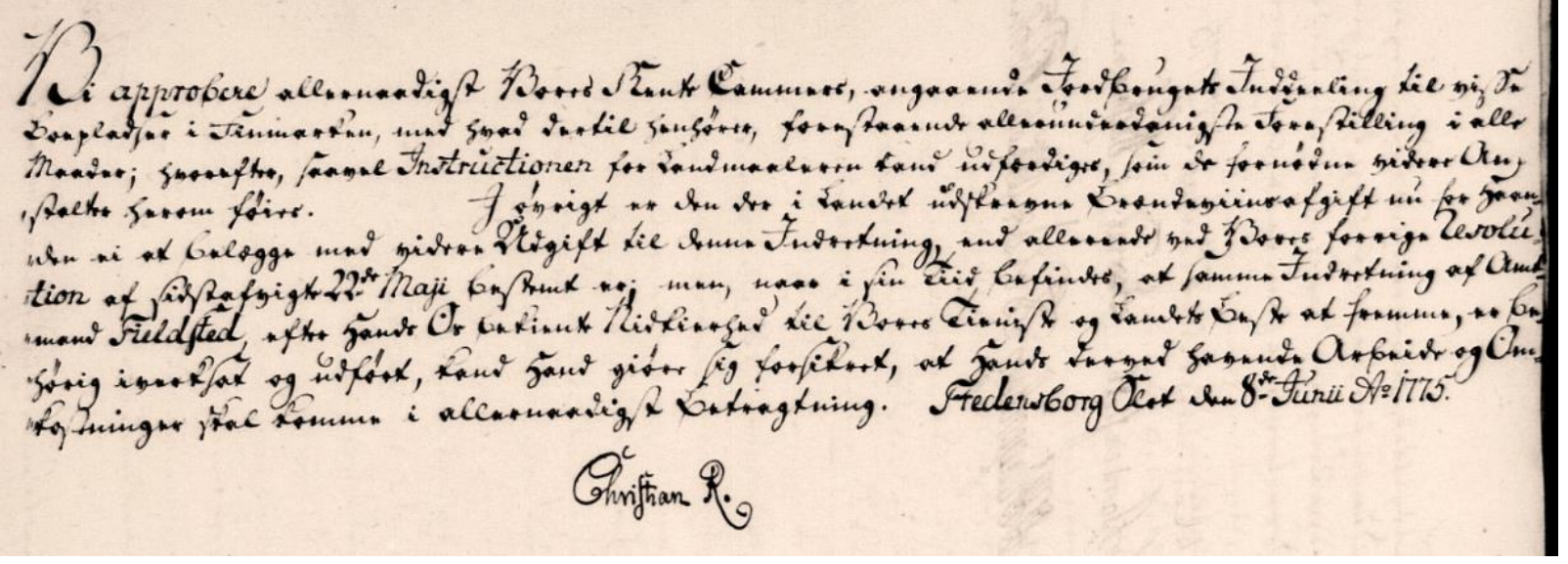

Figur 3. Kong Christian VIIs approbasjon av 1775-resolusjonen innledes slik: Vi approberer allernaadigst Vaares RenteCammers, angaaende Jordbrugets Inddeling til visse Boepladser i Finmarken, med hvad dertil henhører, forestaaende allerunderdanigste Foreslilling [...] Fredensborg slot, den 8. Junii Ao1775. Christian R. Hentet fra Riksarkivet, Rentekammeret, Kammerkanselliet, G/Gf/Gfa/L0057: Norsk relasjons- og resolusjonsprotokoll 1775, digitalarkivet s. 113.

Post 1 regulerer utleggingen av den enkelte oppsitters lodd i fellesskapet, og kan slik sett sies å formulere resolusjonens hovedmålsetting. Den lød slik:

Til enhver fast Boplads anvises saa megen Grund, som udfordres for en Familie, omtrent til fire Qvægs-Høveders, eller for hvert Høved otte Faars, Græsning og Vinter-Foder, dog at derved iakttages: a) hvor En eller Anden haver i Brug visse allerede opryddede Pladser, samme Pladser ham da, saavidt muligt er, tildeles; b) [omhandler jord til geistlige og verdslige betjenter]; og c) hvor Leilighed gives til Rydning, anvises dertil visse Pladser Bostedet til Forbedring.

Post 2 er av oppmålingsteknisk art. Post 3 til 6 omhandler rettigheter. Her reguleres oppsitternes rett der fellesskapet ikke blir oppløst. Kongen tar her forbehold om barskogen og «bortforpaktede Herligheder» på øde steder, men gir også regler for tilbakeføring av forpaktningene «naar disse Steder erholde faste Beboere». Post 6 sikrer at «[d]e Herligheder, som hidintil have været tilfælles for hele Bygder eller Almuen i Almindelighed [...], forblive fremdeles til saadan almindelig Brug». ${ }^{45}$

\footnotetext{
${ }^{44}$ Resolusjonen er inntatt i sin helhet i Fr. Aug. Wessel-Berg, Kongelige Rescripter, Resolutioner og Collegial-Breve for Norge i Tidsrummet 1660-1813, Andet Bind 1746-1780, Christiania 1842, s. 623-625, under 3. juni 1775 [!], i note bemerket «Anføres sædvanlig under Dato 8 Juni». Den finnes også i Tønnesen (1972), s. 136-139. 8. juni 1775 er rett dato for resolusjonen, jf. også Simon Trøan, Om kongelig resolusjon av 08.06.1775 [...], Riksarkivet, brev, 13.12.19 (ref. 2019/22285).

${ }^{45}$ Post 6 er ennå i kraft som norsk lov, se lenke i note 4 ovenfor.
} 
Jordinndelingene i Finnmark: var de Norges eldste offentlige utskiftinger?

I post 7 tar kongen ytterligere forbehold, som med dagens øyne kan framstå som nokså inngripende, men som sett i lys av Kongens høyhetsrett neppe var uvanlige. Forbeholdet gjaldt a) odelsretten, b) en bo- og byggeplikt, samt c) en hjemfallsrett for Kongen, om «Pladsen forlades $\varnothing$ de, og bliver uden Beboere $\varnothing$ de henstaaende over tre Aar». Post 8 påla amtmannen å utstede skjøter eller eiendomsbrev på plassene som deretter skulle sendes Rentekammeret for ratifikasjon. Det er ikke rom for å gå inn i samtlige poster; i det videre ser jeg på dem som kan belyse problemstillingen omkring utskifting. ${ }^{46}$

Post 12 pålegger amtmannen a) å tilse at «Alting dermed ordentlig tilgaaer» og b) avgjøre tvister om «Jordbrugets Uddeling» som måtte forekomme mellom landmåleren og innbyggerne eller mellom innbyggerne innbyrdes «om Grændsernes Bestemmelse, deres nærværende Brug, formeente Rettigheder m. v.». Parter som ikke aksepterte amtmannens beslutning, kunne påanke saken til Rentekammeret «inden sex Maaneder efter at Amtmandens Decision dem er bekjendtgjort». En ordning med anke til Rentekammeret fant man også i den danske utskiftningsloven av $1781 \S \S 4$ og 8 og i det senere utkastet til norsk utskiftningslov av $1811 .{ }^{47}$ I post 12 (c) til (e) blir amtmannen pålagt å sikre landmålerens arbeid ved å holde bok over hans arbeid, kopibok over skjøter og eiendomsbrev samt årlig å underrette Rentekammeret om framgangen $i$ arbeidet.

\subsection{Landmålerinstruksen - hva skulle i praksis finne sted?}

Sammen med resolusjonen fulgte en landmålerinstruks..$^{48}$ Lest sammen med resolusjonen gir den et godt bilde av det som skulle finne sted, delt mellom fire ansvarlige organer.

Landmåleren skulle ifølge instruksen $§ 9$ ved «hver Gaards eller Boeplads Afdeeling» nøyaktig beskrive plassens «Beliggende og Strækning, efter Compasset og ohngefærlige Maal af Lengde og Breede». Dette omfattet også «[d]e Herligheder som henhøre til Pladsen, som Fiskerie [...], Skovland, [osv.]». Bokstav f er her særlig interessant:

Engstykker som ligger i andre Fiorder, eller paa langt bortliggende Stæder fra den Plads, under hvilket de efter forhenværende Brug have henført, skal hand søge at ombytte med andre, som ligger beleilig for hver Opsidder, saaledes, at Pladsernes Jordbrug kand vorde samlet saavidt mueligt er og Landets Beskaffenhed det tillader (min utheving).

\footnotetext{
${ }^{46}$ For dette formål vises det til Ravna (2020), s. 234-236.

${ }^{47}$ Se lovhenvisning i note 15 ovenfor og Juvkam, «Træk fra utskifningsvæsenets historie», s. 65.

${ }^{48}$ Forslag til landmålerinstruks (som antas å samsvare med den vedtatte) finnes hos Tønnesen (1972), s. 392-397, med referanse kgl. Resolusjoner, nr. 12, 8. juni 1775, Rentekammeret, 1. Nordenfjeldske kontor 1775-77. «Indstruction» til landmåleren er omtalt av Wessel-Berg (1842), s. 625, hvor det i note står: «Af denne Indstr. Haves ikke Gjenpart; cfr. Instr. 7 Dec. 1785 og Lov ang. Areal-Indholdet af v. F. V. 6 Juni 1816.
} 
Jordinndelingene i Finnmark: var de Norges eldste offentlige utskiftinger?

Ombytte av engstykker viser at man ikke bare sikter mot å løse opp fellesskapet, men også forestå teigskifte. I $§ 10$ pålegges landmåleren, sammen med fire «uvillige Mænd», å avsi kjennelser i tvister, bl.a. om «den nysnævnte Ombytting (i § 9)». Landmåleren måtte videre ta hensyn til etablert bruk idet han etter $\S 11$ måtte iaktta

at den opryddede Engbund, som enten en PladsOpsidder selv, eller og Opsidderens Fader [...] af egen Drift og Vindskibelighed, have ryddet, eller ved Strævsomhed giort brugbar, maae komme den som paa Jordens Forbedring har arbeidet, eller hands Arvinger, til Nytte.

Landmåleren skulle så (med tingsvitner) fastsette «Immatriculerings Likning» (verdi) på plassen (§ 12). Forretningene skulle nøyaktig innføres i landmålerprotokollen (§ 19) og årlig innrapporteres til amtmannen $(\S 20)$.

Amtmannen skulle på grunnlag av landmålerens inndelingsforretninger utstede skjøte eller eiendomsbrev på plassene, som så skulle sendes Rentekammeret, jf. res. post 8.

Rentekammeret skulle deretter ratifisere (godkjenne) skjøtene, jf. res. post 8. Deretter skulle skjøtene sendes sorenskriveren som besørget de ratifiserte skjøtene tinglyst og innført i panteboka (hvor man i dag kan finne disse). Ved tinglysinga ble eiendommene registrert $\mathrm{i}$ panteregisteret (datidas grunnbok) og tildelt matrikkelnummer.

Resolusjonen og landmålerinstruksen stiller således opp en detaljert prosedyre for inndeling av den umatrikulerte jorda, som formelt (og stedvis reelt) lå i jordfellesskap. Dette ledet til at oppsittere på bebodde plasser fikk sine eksisterende eiendommer beskrevet og matrikulert.

\subsection{Skjøteformularet}

Med resolusjonen fulgte også «Bemeldte Formular «til Eiendoms-Brev eller Skjøde paa en uddeelt Boplads i Finmarken». ${ }^{49}$ Det er en mal for skjøtene som fulgte resolusjonen og som sådan viser Kongens vilje. Den bidrar til å belyse det som skulle finne sted. Det innledes slik:

Christian den Syvende, Konge til Danmark og Norge, ec. ${ }^{50}$ Hans Kongl. Majts. allernaadigst beskikket Amtmand over Vardøhuus Amt, N. N., gjør vitterligt: at efter de til mig indløbne allernaadigste og høie Ordres, samt efter Landmaaler N. N.'s Beskrivelse og Indberetning om Gaard-Pladsen. . . . . . kaldet, anført i Jord-Inddelings-Forretningen for N. N. Sogn Nr., beliggende i N. Fjord med Bygde-Nr. (her beskrives Pladsens Grændser, Engsletter samt Grund-Matriculen eller Skyldsætningen af Ko-Foder saa udførlig, som den af Landmaaleren er opgiven) bliver hermed, paa det Kongl. Rentekammers nærmere Ratification, til Opsidderen N. N. afhjemlet til hans og hans rette og lovlige Arvingers fulde Eiendom, saaledes at han samme Jordplads bruger og besidder, som han det kjøbt eller arvet havde, med alt Tilliggende og inden anførte Grændser

\footnotetext{
${ }^{49}$ Wessel-Berg (1842), s. 625-626.

${ }^{50}$ Skal stå: «De Wenders og Gothers, Hertug udi Slesvig, Holsteen, Stormaren og Dytmarsken, Greve til Oldenburg [...]», jf. skjøtene referert i note 53 nedenfor.
} 
Jordinndelingene i Finnmark: var de Norges eldste offentlige utskiftinger?

beliggende Jordebrug, samt Rettighed til Fiskerie i ferskt Vand eller smaa Elve, som ligge inden Pladsens Grændser, eller derpaa støde, hvilket Alt, ligesom Pladsen, herved bliver bemeldte

Opsidders N. og hans Arvingers eller deres, som han denne Gaarplads giver, bortskjøder eller med lovlig hjemmel overdrager til, Eiendom.

Skjøtet skulle altså utstedes på grunnlag av en «Jord-Inddelings-Forretning». At det ikke står noe om hvem jorda overdras fra, peker på deling fra et udefinert jordfellesskap (og ikke fra Kongens gods). Dette underbygges også av at boplassen er «afhjemlet til hans [skjøtemottakerens] og hans rette og lovlige Arvingers fulde Eiendom [...] som han det kjøbt eller arvet havde» (ikke har kjøpt eller fått i gave). Deretter følger fire vilkår, hvor 1) er plikt til å bebygge eiendommen, «samt udreede de Rettigheder, Skatter, Skydsfærd og offentlige Tyngder, som Almuen i Findmarken ere eller vorde paalagte», 2) unntak fra odelen, og 3) hjemfallsretten, jf. res. post 7 bokstav c og 4) at eiendomsretten ikke måtte gjøre «Hinder i det almindelige Fiskerie».

\section{Hva fant i praksis sted?}

\subsection{Jordinndelings- og skyldsetningsforretninger 1776-1800}

Skjøtene utstedt på grunnlag av forretningene hjemlet i resolusjonen, og som finnes $\mathrm{i}$ pantebøkene for Sorenskriveren i Finnmark, er her nyttige kilder. For denne studien har det vært mulig å undersøke 33 skjøter utstedt fra 1776 til $1800 .^{51}$

Den første forretningen utført i medhold av resolusjonen fant sted i Hasvig sogn i 1776, hvor eiendommen til Hasvig Handel og fem andre eiendommer ble inndelt og fikk skjøter utstedt 19. november $1776 .^{52}$

I skjøtene utstedt av amtmann Thorkel Fieldsted, i perioden 1776-1778, til sammen 16 undersøkte, er med ett unntak ${ }^{53}$ formen «afhiemlet til hans [...] fulde Ejendom» nyttet. ${ }^{54} \mathrm{I}$

\footnotetext{
${ }^{51}$ Disse foreligger dels i transkribert form ved statsarkivet i Troms $\emptyset$ og er dels transkribert av statsarkivar Yngve Nedrebø, Statsarkivet i Bergen.

52 [Utskrift av] Pantebok nr. 1 (1776-1794), Sorenskriveren i Finnmark, Statsarkivet i Troms $\varnothing / S A T \varnothing$, G/Gb/L0001pb: https://media.digitalarkivet.no/view/17338, de to første, som finnes på fol. 7b-8a og 8a-8b. Se også Landmålerprotokoll (for Finmarken) 1776-1845, SATØ, https://media.digitalarkivet.no/view/39721(21.02.21), s. 5 .

${ }^{53}$ Unntaket er skjøtet fol. 7b (se forrige note) hvor «Handels-Pladsen paa Hasvig» ble «afhiemlet og overdraget til hands [handelsmann Pohlmann] og hans Eftermænds, som til at forestaae Hasvig Handel [...] Brugt og Benyttelse $[\ldots] »$.

${ }^{54}$ [Utskrift av] Pantebok nr. 1 (1776-1794), Sorenskriveren i Finnmark, 7b-8a, og 8a-9a, fol. 12b, 121/2, 13b (alle utstedt 19.11.1776, Hasvig Sogn), fol. 14b (Hammerfest Sogn (utdatert), fol. 261/2, fol. 35b, fol. 36, fol. 36b, fol. 361/2, fol. 37, fol. 37b, fol. 38, fol. 39 og fol. 41 (alle utstedt 21.08.1778/Altens Sogn). I tillegg finnes et skjøte, med identisk ordlyd som i formularet, hos Spilling, Av Finmarkens skogret, bilag til Norsk Retstidende no. 4-6 1920, s. 8-10, med henv. til skjøte hjemlet $\mathrm{i}$ «Kongl. Allerhøyest Resolution af 8de Juni 1775», utstedt 9. des. 1777/Alten Sogn.
} 
skjøtene utstedt av amtmann Christen Heiberg i perioden 1782-1787, her 11 stykker, er formen «overdraget til hans [...]» eller «skiødet til hans [...] fulde Ejendom» nyttet. ${ }^{55}$

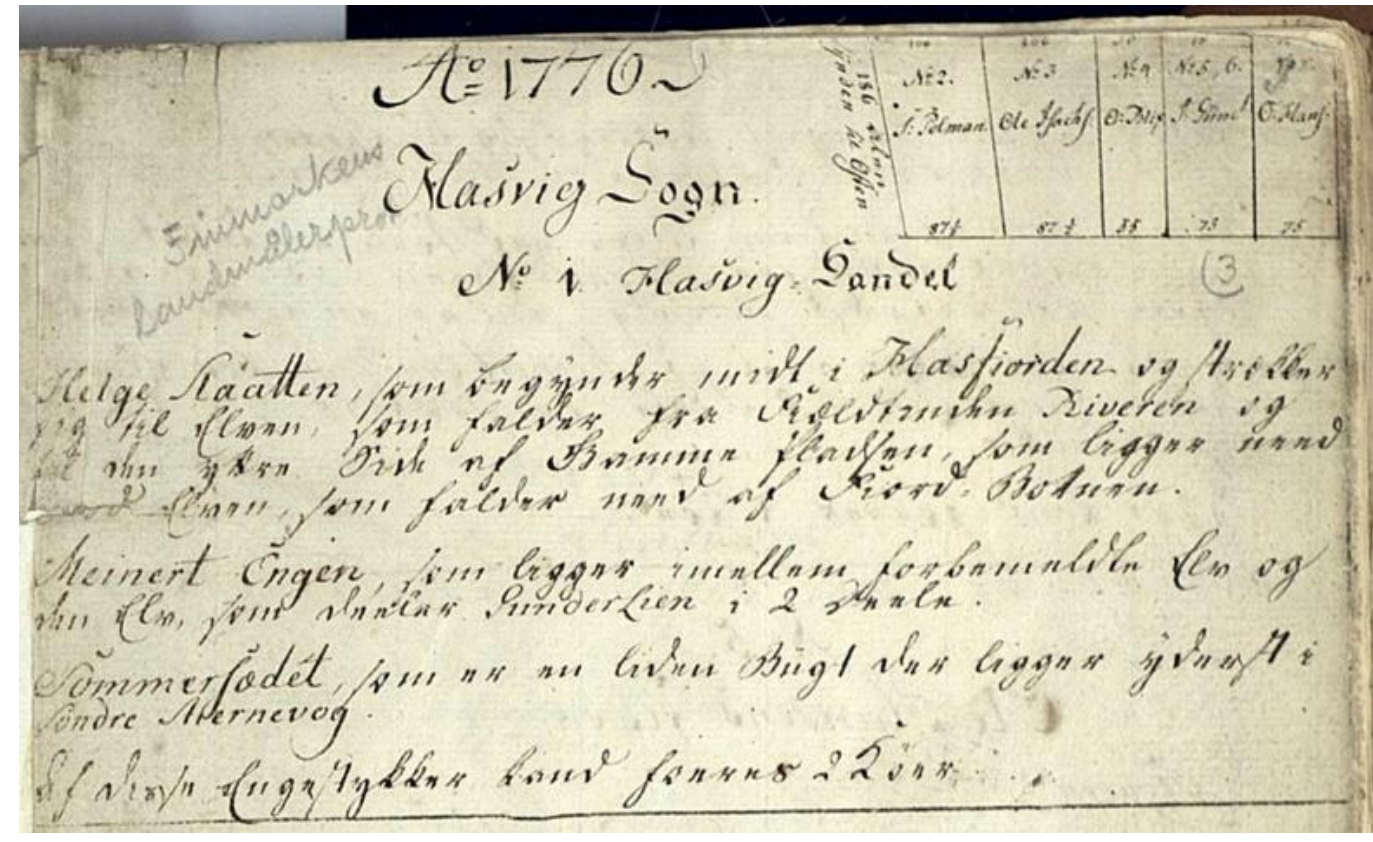

Figur 4. Den første jordinndelingsforretningen i Finnmark fant sted i 1776 og omfattet Hasvig Handel mfl. i Hasvik Sogn (i dag Hasvik kommune). Landmålerprotokoll (for Finmarken) 1776-1845, SATØ, digitalarkivet s. 5.

Videre er seks skjøter utstedt av amtmann Ole Hannibal Sommerfelt i perioden 1788-1800 unders $\varnothing \mathrm{kt} .{ }^{56}$ Også i disse nyttes hovedsakelig formuleringene overdraget eller skjøtet til hans fulde Ejendom. De to første av disse er fra Loppen og Talvik. ${ }^{57}$ Blant disse skjøtene finnes også det første påviste grunnet i en forretning avholdt av en sorenskriver. Den fant sted 21. august 1793 og gjaldt «Jordepladsen Lilleporsangervig» i Kielvigs Præstegield, som 30. desember 1797 på Rentekammers ratifikasjon, ble «skjødet til [oppsitteren] og hands Rette og lovlige Arvingers fulde Eiendom [...] som han den kiøbt eller Arvet havde [...]». Betegnelsen Jordinddelings Forretning er her erstattet av Skyldsatnings Forretning. ${ }^{58}$

Blant disse seks skjøtene finnes to tilfeller hvor jord er solgt. Det ene gjaldt plassen, Stavendahl i Hasvig Sogn, som under jorddelingen i 1776 ble avhjemlet til Christopher Hansen, men som etter hans død hadde ligget øde over 3 år, «hvor over Pladsen følgelig der

\footnotetext{
${ }^{55}$ Utskrift av pantebok nr. 1 (1776-1794), Sorenskriveren i Finnmark, fol. 98 (24.08.1782/Hammerfest Sogn), fol. 101b (16.05.1783/Altens Sogn), fol. 116b, fol. 1201/2, fol. 123a, fol. 128b, fol. 129 (alle utsted 31.05.1783/Kielvig Sogn,) fol. 141b (03.05.1784/Altens Sogn), fol 147b (30.06.1785/Hasvig Sogn), fol. 162 (02.01.1787/Loppens Sogn) og fol. 169 (Maasøe [Sogn] 12.06.1787). I skjøtet fra 1782 er passusen erstattet med etc. - og med en henvisning til skjøte no. 2 , som dessverre ikke er leselig.

${ }^{56}$ Sommerfelt omtaler for $\emptyset$ vrig jordinndelingen og eierforholdene $\mathrm{i}$ «Kort Beskrivelse over Finmarken», Topografisk Journal for Norge, bind 7 (24), 1799 s. 101-179 på s. 143-144.

${ }^{57}$ Utskrift av pantebok nr. 1 (1776-1794), Sorenskriveren i Finnmark, fol 174 (30.06.1788/Loppens Sogn) og fol. 203b204 (05.07.1790/Alten Sogn). Sistnevnte er for sorenskriverens gård og overdras til «fuldkommen Raadighed».

${ }^{58}$ Utskrift av pantebok nr. 2 (1794-1813), Sorenskriveren i Finnmark, fol. 47b-48a (30.12.1797/Kjelvig Sogn).
} 
Jordinndelingene i Finnmark: var de Norges eldste offentlige utskiftinger?

udi adkomst brevet indrykkede 3 Poster Hs Mayts. Hiemfalden igien ligesom den aldrig havde været i nogens Værge eller eie». Ved auksjon 25. mai 1793 ble plassen solgt til kjøpmann Killengreen mot «Hs Mayts. Casse erlagte Kiøbesum Fyrgetyve og otte skilling». ${ }^{59}$ Det andre tilfellet gjaldt «Jorde Pladsen Havesund i Maasøe Præstegjeld» hvor oppsitteren tidligere hadde fått rydningsseddel. Etter skyldsettingsforretning avholdt av sorenskriver Ørum 7. juni 1794 ble plassen «paa det Kongl. Rente Cammer nærmere Ratification solgt skiødet og afhondet til [oppsitteren] og hans rette og lovlige arvingers fulde Eiendom». ${ }^{60}$ Det framgår ikke hva kjøpesummen var eller om den er betalt.

Den 23. aug. 1799 fant det sted en forretning avhold av konst. sorenskriver Rist over boplassen Schiøttenberg i Kiøllefiord Sogn, hvoretter plassen til «Opsidderen og Rydningsmanden Johannes Erichsen paa det det Kongl. Rentekammers nærmere Ratification skiødes til hans [...] fulde Eyendom [...] som han den kiøbt eller arvet havde [...]». ${ }^{61} \mathrm{I}$ motsetning til foregående forretning, hvor rydningsjord muligens ble solgt, tyder intet på at det skjedde her.

I perioden 1776-1790 er samtlige skjøter utstedt på grunnlag av jordinndelingsforretninger. Forretningene er, med ett eller to unntak, ${ }^{62}$ oppmålt av landmåler Christian Frost Bredal. De senere skjøtene i perioden er utstedt på grunnlag av skyldsetningsforretninger. Amtmann Fieldsted nytter - som vi har sett - formen «afhiemlet til [...] fulde Ejendom», slik formulert i skjøteformularet. Senere amtmenn nytter «overdraget» eller «skiødet» til, uten at det noe sted framgår fra hvem. Det peker på at delingen skjer fra et udefinert jordfellesskap. ${ }^{63}$ Embets- og handelsmenn fikk for øvrig ikke plassene til eiendom, men til bruk og rådighet.

\subsection{Skyldsætningsforretninger 1803 til 1815}

For perioden 1803-1815 er sju skjøter, basert på Opmaalings og Skyldsaetnings Forretninger eller Skyldsatningsforretninger, unders $\varnothing \mathrm{kt}$. Tre av disse er utstedt etter at unionen med Danmark var over. For perioden 1803-1804 finner vi tre skjøter utstedt av amtmann Martin A.

\footnotetext{
${ }^{59}$ Utskrift av pantebok nr. 2 (1794-1813), Sorenskriveren i Finnmark, fol. 5a (30.12.1793/Hasvig Sogn).

${ }^{60}$ Utskrift av pantebok nr. 2 (1794-1813), Sorenskriveren i Finnmark, fol. 6a-6a (24.06.1794/Maasøe Sogn) (min utheving).

${ }^{61}$ Utskrift av pantebok nr. 2 (1794-1813) for Finmarken sorenskriveri, fol. 63 (01.05.1800/Kiøllefiord Sogn).

${ }^{62}$ Unntakene er skjøte fol. 128b og antatt fol. 123a (se note 55 ovenfor) som er oppmålt av Ole Nikolaj Giфrup. Christian VII beskikket to landmålere for Finnmark, nevnte Bredal for Vest-Finnmark i 1775 og Giørup for ØstFinnmark i 1778. Det finnes ikke dokumentasjon på Giørups arbeid i Øst-Finnmark utover nedtegnelser i ministerialbok (kirkebok) nr. 2 (1764-1821) for sokneprestkontor; se Øyvind Ravna, «Nye bidrag til eiendomshistorien i Finnmark», Heimen nr. 1/2017, s. 6-27 på s. 18-21. Skjøtene fol. 128b (og fol. 123a) er basert på målinger Giørup utførte i Kielvig Sogn i 1782. De finnes ikke i landmålerprotokoll (for Finmarken) 1776-1845.

${ }^{63}$ I andre samtidige skjøter fremgår det hvem som er selger, f.eks. i utskrift av pantebok nr. 1 (1776-1794), Sorenskriveren i Finnmark, fol. 191b (skjøte) og pantebok nr. 2 (1794-1813), Sorenskriveren i Finnmark, fol. 244b (Auctions Skiøde).
} 
Jordinndelingene i Finnmark: var de Norges eldste offentlige utskiftinger?

Unmack, basert på forretninger avholdt av sorenskriver Elias Friderich Hetting, som alle skjøtes oppsitterne til eiendom. ${ }^{64}$

De fire siste undersøkte skjøtene er fra perioden 1810-1815. Den 30. oktober 1810 ble jordplassen Utze Giedde i Hammerfest Sogn oppmålt og skyldlagt (ikke oppgitt av hvem), og deretter skjøtet til Mathias Johansen Ballajock til hans «fulde Eiendom» av amtmann Hilmar Krohg. ${ }^{65}$ To skjøter, basert på oppmålinger 22. mars og 23. mai 1811 for eiendommer i Koutokeino og Afjuvarra Sogn, ble av amtmann Johan C. Krogh «paa vedkommende Departements nærmere Ratification», skjøtet til Peder Pedersen Audagoski og Jens Hansen, for begge til deres «fuldkomne Eiendom» 27. september $1815 .{ }^{66}$ Samme dato ble jordplassen Galdo Belles i Tanen Sogn, som var oppmålt og skyldsatt 31. mars 1815, skjøtet til Clemet Erichsen. ${ }^{67}$

For skjøter utstedt i perioden 1810-1815 nyttes formen «skiøtet til bemeldte [navn] til hans og hans lovlige Arvingers fulde [eller fuldkomne] Eiendom [...] som han den kjøbt eller arvet havde [...]». Det er ikke mulig å påvise forskjeller i formuleringer eller det materielle innhold før og etter oppløsningen av unionen med Danmark. Det er heller ikke mulig å påvise forskjeller i materielt innhold i forretningene gjennom hele den unders $\phi k t e$ perioden, innbefattet siste kvartal av 1700-tallet. ${ }^{68}$

\subsection{Utskifting med aarlig skiffteviis slått}

For en «Jordeplads» i Koutokeino og Afjuvarra Sogn finnes det en svært interessant forretning som skiller seg fra de foran beskrevne, avholdt 28. mars 1814. Selv om den betegnes som skyldsatningsforretning, har den et innhold hvor det framgår at det materielt dreier seg om utskifting. Forretningen, som ble avholdt av sorenskriver Knudssøn og menn, gjaldt en bebodd «Jordeplads i Karrasjok». ${ }^{69}$ Den innledes med oppmåling av boplassen. Av det protokollerte framgår det at «[d]a denne Plads forhen har været brugt under et med den 25 Martj 1811 under No-V opmaalte Plads, saa bleve begge Opsiddere som nu tilstæde, eenige om, at de til Pladserne liggende Engesletter skal bruges og ejes saaledes: [her følger en beskrivelse av deling engslåttene mellom de to oppsitterne og en tredje part, og videre hvilke slåtter som hører til hver plass og part]». Forretningen fortsetter med beskrivelse av regler om «Aarlig

\footnotetext{
${ }^{64}$ Utskrift av pantebok nr. 2 (1794-1813) for Finmarken sorenskriveri, hhv. fol. 124-124b, 125a (Lebesbye og Oxfiordbunden i Kiøllefiord Sogn) og fol. 137b-138a (Stangnæs i Hammerfest Sogn).

${ }^{65}$ Utskrift av pantebok nr. 2 (1794-1813) for Finmarken sorenskriveri, fol. 251 b (12.12. 1810/Hammerfest Sogn).

${ }^{66}$ Utskrift av pantebok nr. 3 (1813-1831) Vest-Finnmark sorenskriveri, fol. 81-83 (Koutokeino og Afjuvarra Sogn).

${ }^{67}$ Utskrift av pantebok nr. 1 (1817-1862) for Tana sorenskriverembete, fol. 3 (Tanen Sogn).

${ }^{68}$ Studien omfatter også et antall skjøter basert på forretninger etter 1815 og fram til ca. 1860. Plassen tillater ikke drøfting av disse. Kort fortalt følger de samme oppsett og har innhold som forretningene beskrevet ovenfor.

${ }^{69}$ Utskrift av Justitsprotokol for Finmarkens sorenskriveri 1813-1822, aut. 27 febr. 1813. fol. 130.
} 
Jordinndelingene i Finnmark: var de Norges eldste offentlige utskiftinger?

skiffteviis» slått, eller årkast, hvor det gis regler for hvem som kan bruke de enkelte teigene i bestemte år. Slike bruksregler er tidstypiske for datidens utskiftningsforretninger. ${ }^{70}$

\subsection{Utskiftinger i Trondhiems stift per 1803}

Etter at Danmark fikk sin utskiftningslov i 1781, ble det påstartet et arbeid med en tilsvarende lov for Norge. I 1803 sendte Rentekammeret ut på høring et sirkulær med et utkast til en slik lov. ${ }^{71}$ Sammen med høringen ble amtmennene bedt om å innhente opplysninger om eksistensen av jordfellesskap og om det hadde funnet sted utskifting i amtene mm. ${ }^{72} \mathrm{Ut}$ fra svarene laget Rentekammeret en oversikt over jordfellesskap og avholdte utskiftinger i Norge. Oversikten, som er gjengitt av O. Juvkam, innehar detaljerte opplysninger for de enkelte amter, herunder Finmarkens. ${ }^{73}$

Under Trondhiems stift, som bl.a. omfattet Nordlands og Finmarkens Amt, kan man for Nordlands Amt lese at «[p]aa de allerfleste Gaarde er alt i Fælledskab under Navn av Teigskifte, Aarbytte og Hopmark, det sidste er med Hensyn til Skov». For Finmarkens Amt er det kort anført «Ligeledes». ${ }^{74}$ Med andre ord lå det meste av jorda i amtet i teigblanding eller jordfellesskap. På spørsmål om «Udskiftningen [har] været attraaet forsøgt og fuldført og hvorledes var Fremgangsmaaden», finner man for amtene under Trondhiems stift følgende svar: For Trondhiems Amt meldes det at «[b]etydelig fremgang hermed er ej giort [hvoretter fremgangsmåten beskrives]». I Romsdahls Amt er «Udskiftningen [...] af mange attraaet men af faa fors $\varnothing \mathrm{gt}$ og fuldført». For Nordlands Amt heter det at «[d]et Tilfældet at nogen har forlangt Udskiftning, har aldrig forekommet Amtmanden». For Finmarkens Amt, derimot, kan man lese: «Udskifting i senere Tiid er meget attraaet og udført ved Sorenskriver og Mænd samt angrændsende Naboers Tilkaldelse.» ${ }^{75}$ Det ble her videre anført at det er «uden for al Tvivl at Udskiftning forhøier Eiendommens Værd, da først faaer Landmanden Lyst til at forbedre Jord og Mark». ${ }^{76}$ Amtmann Martin A. Unmack omtaler her ganske sikkert de oppmålings- og skyldsetningsforretningene han hadde utstedt skjøte på grunnlag av, og trolig også forretningene forut for hans tid som amtmann.

Svarene til Rentekammeret viser at innen Trondhiems stift hadde utskifting hovedsakelig funnet sted i Trondhiems og Finmarkens amt. I Finnmark hadde man dessuten også gode

\footnotetext{
${ }^{70}$ Begrepet «fellesskap» omfattet også årkast i utskiftningsloven av 1821, se Borgedal (1959), s. 160.

${ }^{71}$ Juvkam (1917), s. 44.

${ }^{72}$ Norge fikk sin utskiftningslov i 1821, jf. lov 17. August 1821 angaaende Jord og Skovs Udskiftning av Fællesskab. Spørsmålet var likevel relevant da det kunne utføres utskiftinger i privat regi i medhold av NL 3-12-15.

${ }^{73}$ Juvkam (1917), s. 43-56.

${ }^{74}$ Juvkam (1917), s. 48.

${ }^{75}$ Juvkam (1917), s. 52 (min utheving). I Juvkam (1948) reflekteres det ikke over disse sentrale opplysningene.

${ }^{76}$ Juvkam (1917), s. 54
} 
erfaringer med dette. Den samtidige oppfatningen var således at det hadde foregått betydelige utskiftinger i Finnmark, noe som naturlig må ha skjedd med hjemmel i 1775-resolusjonen.

\section{Omtale i samtidig litteratur og forslag om egen utskiftningslov}

\subsection{Omtale i samtidig litteratur}

Samtidig litteratur er også en kilde til kunnskap om hva resolusjonen initierte. En slik kilde er Beskrivelse over Kongeriget Norge fra 1796 av Lars Hess Bing. Om Finmarkens Amt skriver Bing at det var foreslått jorddeling der allerede i 1757, men den «kom ikke til Virkelighed førend ifølge Kongel. Befaling af 27 Maj 1775, efter Forslag af T. Fieldsted».

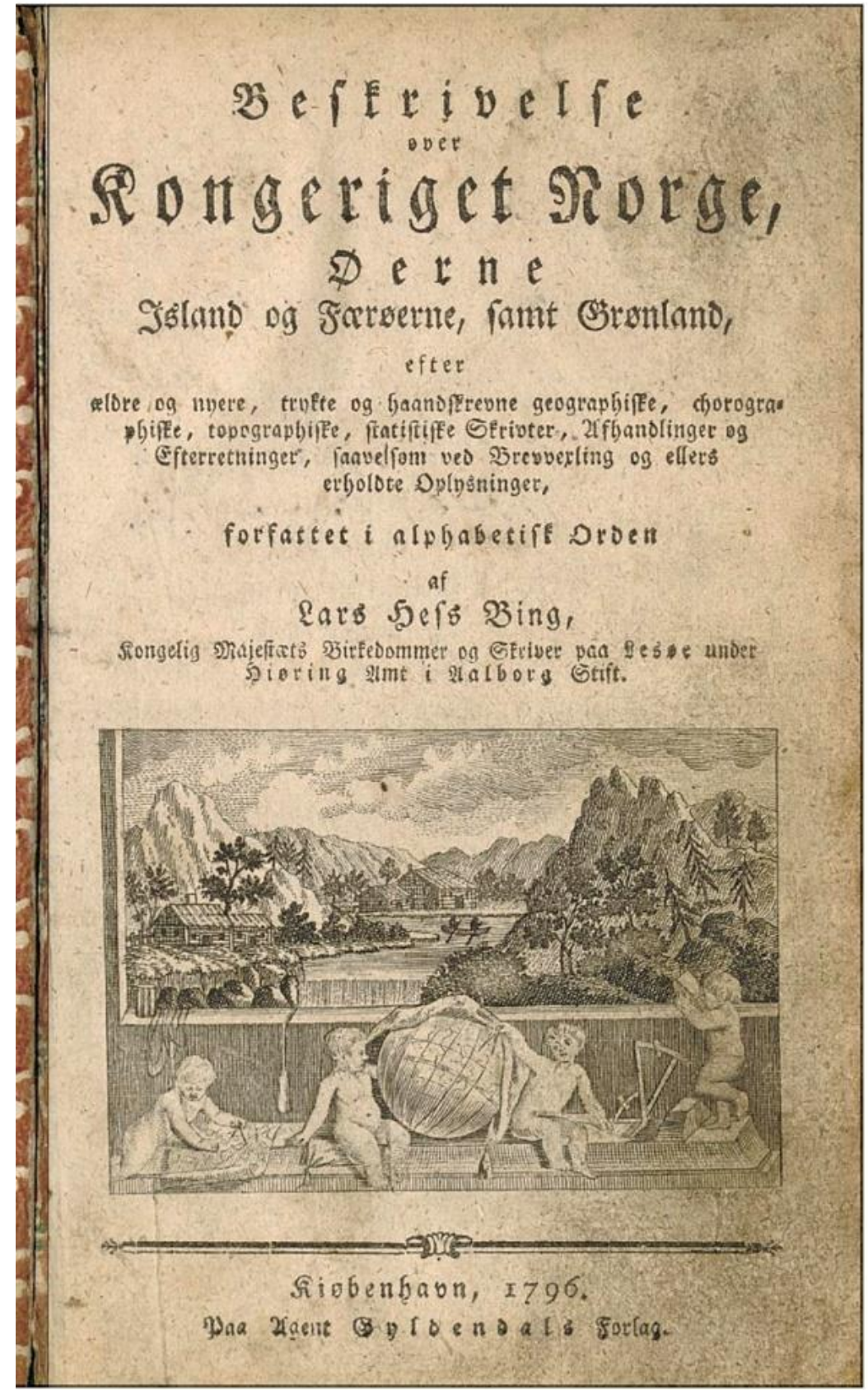

Figur 5. I Beskrivelse over Kongeriget Norge, Øerne Island og Færøerne, samt Grønland av birkedommer og skriver Lars Hess Bing fra 1796 framgår det at det $i$ Vest-Finnmark i 1789 var utstedt eiendomsskjøter på «alle til den Tid opryddede og indtagne Jorder eller Engesletter», noe som omfatter jorder til 629 boplasser. Hentet fra Nasjonalbibliotekets digitale bokhylle. 
Jordinndelingene i Finnmark: var de Norges eldste offentlige utskiftinger?

Da ble to landmålere ansatt, en i Øst-Finnmark og en i Vest-Finnmark, for å utføre jorddelingen:

I Øst-finmarken blev Jorddelingen [...] opphævet, formedelst de dermed forbundne

Vanskeligheder, som flød af Landets Beskaffenhed, Indbyggernes Tænkemaade og omflakkende

Levemaade [...]. I Vestfinmarken Derimod gik den frem, og blev fuldført Aar 1789 over alle til

den Tid opryddede og indtagne Jorder eller Engesletter, og Eiendoms Skiøder paa de uddeelte

Pladse bleve givne. Derved er nu matrikulerede Jorder til 629 Boepladse, under følgende 6

Tinglave, som Vestfinmarken indeholder. ${ }^{77}$

Bing, som var utdannet topograf og jurist og således velkvalifisert til å forstå så vel juss som landmåling, nytter her begrepet jorddeling. At den første tidshenvisningen sammenfaller med starten på det danske arbeidet med å få i gang utskiftinger, er neppe heller tilfeldig. At man ikke lyktes med jorddelingen i Øst-Finnmark, kan forklares med flere forhold. ${ }^{78}$

En annen samtidig kilde er Jens Rathke, senere Norges første professor i naturvitenskap. I 1802 besøkte han Finnmark, og skriver da at «Landets Udskiftning til Eiendom fandt som bekiendt til Uheld saa meget Modsigelse i Østfinmarken, at den ei kunde iværksættes». ${ }^{79}$ Dette medførte at «Græsset kan altsaa ikke fredes til Høeslet uden i afsides Egne» og at bøndene måtte bruke «Reensmosse [...] til «Qvægets Vinterfoering». ${ }^{80}$

Oppfatning om jorddeling i Vest-Finnmark bekreftes også av professor i lovkyndighed Johan Frederik Schlegel, som skriver at det ikke er gjort stor framgang i åkerbruket i Finnmark: «I Altens Tinglav er Jordbruget i bedre Tilstand end paa andre Steder i Finmarken, hvilket fornemmelig bør tilskrives Jorddelinger». ${ }^{81}$ Også jurist, historiker og statistiker Jens Kraft omtaler jorddelingen i hans store seksbinds verk Topografisk-Statistisk Beskrivelse over Kongeriget Norge. Han skriver at det ved res. av 27. mai 1775 ble bestemt «at Jorder eller Bopladser skulde utlægges til Eiendom».

I Vest-Finmarken har Jord-Uddelingen gjort gode Fremskridt og beløp i 1828 Skylden paa de der skyldlagte Pladser sig til 899 Køer 6 Faar, men i Øst-Finmarken, hvor Jord-Uddeling endu i 1828 kun havde fundet Sted i Kjøllefjords og Tana Thinglauge, utgjorde Skylden s. a. ikkun 124 Køer og 3 Faar. $^{82}$

\footnotetext{
${ }^{77}$ Lars Hess Bing, Beskrivelse over Kongeriget Norge, Øerne Island og Farøerne, samt Grønland, Kiøbenhavn 1796, s. 146-147. Tinglagene var Hammerfest, Loppen, Hasvig, Maasøe, Alten og Kiælvig.

${ }^{78}$ Ravna (2020), s. 242-243.

${ }^{79}$ Jens Rathke, Afhandling om de norske fiskerier og beretninger om reiser i aarene 1795-1802 for at studere fiskeriforhold m.v., Bergen 1907, s. 144.

${ }^{80}$ Rathke (1907), s. 153.

${ }^{81}$ Joh. Fr. W. Schlegel, Statistisk Beskrivelse af de fornemste europaeiske Stater, Første Deel, Kiøbenhavn 1793, s. 241.

${ }^{82}$ Jens Kraft, Topografisk-Statistisk Beskrivelse over Kongeriget Norge, sjette deel, Det Nordenfjeldske Norge, Anden

Deel, Christiania 1835, s. 611.
} 
Jordinndelingene i Finnmark: var de Norges eldste offentlige utskiftinger?

Like interessant som Krafts beretning om jordutdeling er hans anførsel om at «hele Landet [i Finmarken] var et Staten tilhørende Sameie, hvoraf Indbyggerne i Flæng betjente sig». ${ }^{83} \mathrm{Med}$ «Staten tilhørende» sikter Kraft ganske sikkert til statens overeiendomsrett, ${ }^{84} \mathrm{dvs}$. at landet var en del av staten Norge. Om han mente at landet var statens private eiendom, ville utsagnet om sameie vært selvmotsigende.

\subsection{Commissionen til Finmarkens Opkomst}

Commissionen nedsatt for at foretage Undersфkelser om Midlerne til Finmarkens Opkomst fra 1826 er en ytterligere kilde til kunnskap om eiendomsforholdene i Finnmark. ${ }^{85}$ Her bekreftes det at det hadde funnet sted jorddeling i Vest-Finnmark, men ikke i øst. I kommisjonsmøtene i Vardø, Vadsø og på Mortensnes framkom det at det ikke eksisterte skyldsatt jord langs Varanger, men at mange i sognet nyttet jord «uden at have Amtsseddel eller Kgl Skjöde paa samme». ${ }^{86}$ Også i sognene Thanen, Læbesbye og Kjöllefjord brukte de «Fleste [Jord] uden nogen lovlig Adkomst». I Vest-Finnmark var derimot det meste «Eiendoms-Jorder», ${ }^{87}$ altså matrikulert jord. Dette bekrefter beretningene til Bing, Rathke og Kraft.

I motsetning til nevnte forfattere mente kommisjonen at all jord som ikke var bortskjøtet, «tilhörer Staten». Dette er også et av de første tilfellene hvor begrepet statens - og ikke kongens - jord nyttes, og hvor retten synes å omfatte mer enn en overeiendomsrett. Like fullt beskrev kommisjonen «et Fælledsskab [...] mellem Staten og Eierne af Engstykkerne». Dette sameie var så omfattende at den foreslo det utskiftet i medhold av utskiftingsloven av 17. august 1821. Utskiftingen skulle «skee saaledes, at hver Lodseier faar det som tilfalder ham, saavidt mueligt, samlet paa et Sted». ${ }^{88}$ Kommisjonen innså imidlertid at dette ville være vanskelig da «Udskiftningen hos Mængden af dem som eie Engstykker, og som ei indsee deres eget Bedste, vil möde stor Uvilje». Mulig det var årsaken til at kommisjonen foreslo en egen utskiftningslov for Finnmark. ${ }^{89}$ Forslaget er grunnet på en oppfatning om at jord som ikke var bortskjøtet, var statens, samtidig som det viderefører noen av postene i 1775-resolusjonen. Paragraf 16 var imidlertid ny:

\footnotetext{
${ }^{83}$ Kraft (1835), s. 560 (min utheving).

${ }^{84}$ Se punkt 1.4 ovenfor.

${ }^{85}$ Se Forhandlings Protocol Commissionen der er nedsatt for at foretage Unders $\phi$ kelser om Midlerne til Finmarkens Opkomst 1826, http://xml.arkivverket.no/diverse/forhandprotfinnmarkkomm1824-30.pdf (20.10.21). Kommisjonen ble ledet av tidl. amtmann i Finnmark Hilmar Meincke Krohg.

${ }^{86}$ Forhandlings Protocol (1826) fol. 4b, 7a og 8b.

${ }^{87}$ Forhandlings Protocol (1826), hhv. fol. 11b, 14b og $16 \mathrm{~b}$.

${ }^{88}$ Forhandlings Protocol (1826) fol. 39b.

${ }^{89}$ Se note 10 ovenfor.
} 
Jordinndelingene i Finnmark: var de Norges eldste offentlige utskiftinger?

Da Fælledsskab finder Sted saavel i Vest som Øst-Finmarken mellem de af Staten i sin Tid bortskiødede Jorder og den Staten endnu tilhørende Jord og Mark, tildeles ogsaa mellem Ejendoms-Jorderne indbyrdes, hvilket Fælledsskab efter Loven af 17de August 1821 bør hæves, skal den saaledes fornødne Udskiftning udføres af en Commission, bestaaende af Districtets Sorenskriver og Landmaaleren; de dermed forbundne Omkostninger udredes af Statscassen [...]. Det er en Selvfølge, at hvor Statens Jord og Mark støder til Eyendomsjorder maae Udskiftning foregaae forinden den ovenfor bestemte Jordinddeling kan finde Sted. -

Ved Udskiftningen tildeles ethvert Jordbrug tillige en passende Strækning til Udmark, og følger den Løvskov der findes paa det udskiftede Brug som Eiendom med Bruget.

Utskiftingen skulle foregå etter reglene i 1821-loven, men til forskjell fra denne, hvor minnelig utskifting var hovedregelen, jf. § 7, foreslo kommisjonen at utskiftingen i Finnmark skulle utføres av en kommisjon og på statens regning. For øvrig beskrev kommisjonen «Fælledsskab» også i Øst-Finnmark, hvor det på dette tidspunkt knapt hadde funnet sted jorddeling. ${ }^{90}$

\section{Drøfting og avslutning}

Kgl. Resolution ang. Jordbrugets Inddeling til visse Boepladser initierte jordinndeling. Det kan det knapt nok argumenteres mot da dette framgår av forarbeidene, skjøteformularet og senere utstedte skjøter. Det framgår også av resolusjonens tittel, uavhengig av om man velger å vektlegge den Kong Christian VII nyttet ved approbasjonen 8. juni 1775 (uthevet ovenfor), eller den som er nyttet i Norges lover (se note 4)..$^{91}$

For å vurdere om denne jordinndelingen reelt sett var utskifting, må resolusjonens ordlyd, forarbeider og formål vektlegges. Vel så viktig er dens landmålerinstruks og ikke minst skjøtene utstedt i medhold av jordinndelingsforretningene. Samtidig litteratur, samt samfunnsog landbruksutvikling, er naturlig også av interesse.

Promemoriaet til amtmann Fieldsted, som er 1775-resolusjonens mest sentrale forarbeid, peker på at Fieldsted fremmet et utkast til en lov for å dele inn et udefinert jordfellesskap i individuelle eiendommer, antakelig inspirert av datidens utskiftinger i Danmark. ${ }^{92}$ Fieldsted var som nevnt medlem av Det Kongelige Danske Landhusholdningsselskab, stiftet i 1769 med formål å motivere og støtte jordbrukere og håndverkere, bl.a. ved å formidle kunnskap og å

\footnotetext{
${ }^{90}$ Jf. Kraft (1835), i punkt 4.1 ovenfor og kommisjonens egen beskrivelse i første avsnitt i punkt 4.2.

${ }^{91}$ Det er tidligere vist at jordinndelingen ikke besto i at Kongens jord i privatrettslig forstand kostnadsfritt ble utdelt til oppsittene i Finnmark, se Ravna (2020). Det kan her medtas, som vist i punkt 1.3, at Kongen, utover krongodsene, ikke hadde annen eiendomsrett til jord i riket enn overeiendomsretten. Dette var en forvalterrett som innbefattet rett til å måle ut rydningsjord i allmenningene og til å beskatte den.

${ }^{92}$ Foruten det refererte i punkt 2.2 kan det pekes på at Fieldsted oppholdt seg i København da han skrev sitt promemoria; se Gudmund Sandvik, «Statens grunn i Finnmark [...]» i NOU 1993: 34 s. 334-380 på s. 363.
} 
Jordinndelingene i Finnmark: var de Norges eldste offentlige utskiftinger?

skape debatt om aktuelle temaer innen jordbruk o.1. ${ }^{93}$ Dette knytter også utviklingen til kameralismen, en økonomisk retning innen statlig finans bygget på tanken om nytten av å støtte opp om næringslivet. Retningen hadde på denne tiden hadde stor oppslutning i Danmark. $^{94}$

I Fieldsteds tanke om å forbedre jordbruket var det ikke plass til et fortsatt jordfellesskap. Han $\emptyset$ nket derimot planmessig inndeling av jord til eneeie. Fieldsted grunnet inndelingen $\mathrm{i}$ at oppsitterne da kunne vite «sine Jordbrugs Grændser og være viss paa til Ejendom for sig og sine at beholde den Plads Han dyrker, optager og forbedrer». I tillegg ønsket han å legge til rette for rydningsplasser.

Formålet, slik det framgår av Rentekammerets forestilling, gjenspeiler dette. Det var «at bringe Jordbruget i Finmarcken til en ordentlig og bedre Benyttelse» ved «at afvænde Indbyggerne fra den hidtil sædvanlige og for Landet skadelige Omflakning, og derimod at tage fast Boepel». Det ga dem mulighet til «bedre at [anordne] Jordbruget, som et Hielpemiddel til deres Underholdning» og «Folkeformerelsen der i Landet».

Formålet gjenspeiles også i resolusjonens post 1. Den la til grunn at «enhver fast Boplads» skulle få anvist «saa megen Grund, som udfordres for en Familie, omtrent til fire QvægsHøveders [...] Græsning og Vinter-Foder». ${ }^{95}$ Under denne anvisning, eller mer riktig inndeling, skulle det iakttas at den som «haver i Brug visse allerede opryddede Pladser, samme Pladser ham da, saavidt muligt er, tildeles». Videre skulle det, om ryddig av jord var mulig, «anvises dertil visse Pladser Bostedet til Forbedring».

Målsettingen var med andre ord at fellesskapet skulle oppløses slik at 1) allerede opptatt jord ble utlagt brukeren til eneeie med et omfang tilstrekkelig til å fø en familie, samtidig som det 2) skulle legges til rette for jordrydding for å forbedre bruket. Om dette også omfattet jord til nye rydningsbruk, er vanskelig å lese av post 1 . Videre viser landmålerinstruksen at teigbytte var aktuelt. Skyldsetting og utferdigelse av skjøte eller eiendomsbrev som dokumentasjon på eiendomsrett, og grunnlag for skattlegging, var også en del av det som skulle gjennomføres - og som ble gjennomført.

Samlet peker dette på at resolusjonen initierte en form for utskifting. Vi har også sett at Fieldsted nettopp nyttet begrepet «udskiftte og sætte Grændser for de nu beboede Pladser», noe som understreker dette. Post 1 er således en utloddingsbestemmelse som vektlegger etablert

\footnotetext{
${ }^{93}$ Claus Bjørn og Ove W. Dietrich, «Det Kongelige Danske Landhusholdningsselskab», Den Store Danske på denstoredanske.lex.dk (2009), jf. Det Kongelige Danske Landhusholdningsselskab på 1769.dk.

${ }^{94}$ Trond Bergh og Tore J. Hanisch, Vitenskap og politikk: Linjer i norsk sosialфkonomi gjennom 150 år, Oslo 1984, s. $15-16$.

${ }^{95}$ Post 1 er i sin helhet gjengitt i punkt 2.3 ovenfor.
} 
Jordinndelingene i Finnmark: var de Norges eldste offentlige utskiftinger?

bruk. Et argument mot at dette kan ha vært utskifting, er at størrelsen på de utlagte eiendommene som utgangspunkt skulle være lik. Her må det imidlertid tas i betraktning at det ikke har eksistert et leilendingsvesen i Finnmark, og at land- eller matrikkelskyld som i alminnelighet ble nyttet som delingsnøkkel ved oppløsning av jordsameie, først ble innført sammen med jorddelingen påbegynt i 1776. Et alternativt skiftegrunnlag kan imidlertid være etablert bruk, ${ }^{96}$ og slik post 1 (a) er formulert, synes slik bruk å ha hatt vesentlig betydning for grunnlaget for jordinndelingen. Praksis fra de gjennomgåtte skjøtene viser da også at det i all hovedsak var allerede eksisterende boplasser og engslåtter som ble beskrevet ved inndelingen, og at det dermed ble lagt vekt på etablert bruk. ${ }^{97}$ For $\emptyset v$ rig var jorddelingene kostnadsfrie. Om det ikke alene underbygger at dette var utskifting i streng forstand, viser det $\mathrm{i}$ alle fall at det ikke var «utvisning» av statens jord som fant sted. ${ }^{98}$

Post 3 til 6 omhandler rettigheter som ikke blir individualisert gjennom oppløsning. Post 7 inneholder bl.a. hjemfallsretten c), som det ikke er grunn til å drøfte med henblikk på om resolusjonen initierte utskifting. Lagt til grunn Kongens overeiendomsrett til allmenningene er det neppe heller grunn til å problematisere den på annet grunnlag. ${ }^{99}$ Post 12 b), som omhandler behandling av «Tvistigheder ved Jordbrugets Uddeling [...] imellem Landmaaleren og Indbyggerne, eller mellem Indbyggerne indbyrdes, om Grændsernes Bestemmelse, deres nærværende Brug, formente Rettigheder m.v.», synliggjør som nevnt en rettsmiddelordning ikke ulik den ordning som finnes i den danske utskiftningsloven av 1781.

Det er også naturlig å se til den danske utskiftningsloven når det gjelder begrepsbruk, hvor begrepene «tildelt[e] Jord» og «Inddelingen» nyttes i $\S \S 4$ og 7 og «Uddeling til Fællesskabets Ophævelse» i $§ 27$ (se note 15 ovenfor). Tildeling og utdeling utgjør som vist i nevnte note det man i senere utskiftningslover kalte utlodding, altså utleggingen av teiger etter oppløsning av jordsameie eller ombytte av grunn. Når tilsvarende begreper nyttes i landmålerinstruksen $\S \S 2$ og 6, må de antas å ha samme mening. I instruksen $\S 6$ finner man også begrepene «afdeling» og «Beboernes Fællesskab». Også i Rentekammerets utkast til en utskiftningslov for Norge fra 1811 finner vi begrepene «Tildeeles» $(\S 16)$ og «Inddeeling» $(\S 17),{ }^{100}$ selv om «udskiftes» og «udlægges» (§ 9) nyttes om det som i senere lover betegnes som utlodding.

\footnotetext{
${ }^{96}$ Se Juvkam (1917), s. 61-62, hvor det vises til Rentekammerets forslag til utskiftningslov for Norge av 1811§ 12, hvor skiftegrunnlaget kunne utliknes av lodseierens «Grændser for deres Brug, efter disse, men ellers efter det Antal Kreaturer enhver Lodsejer beviisligen i de sidste 20 Aar upaatalt har havnet i Udmarken».

${ }^{97}$ Dette støttes også av det siterte av Hess Bing (1796) i punkt 4.1 ovenfor.

${ }^{98}$ Staten vil ganske sikkert ha tatt betalt for overdragelse av jord, se Finnmarkskommisjonen (2019), s. 189 med henvisning til Otto Jebens, Om eiendomsretten til grunnen i Indre Finnmark, Oslo 1999, s. 454.

${ }^{99}$ Se for $\varnothing$ vrig Ravna (2020), s. 255.

${ }^{100}$ Juvkam (1917), s. 64.
} 
Jordinndelingene i Finnmark: var de Norges eldste offentlige utskiftinger?

I tillegg til resolusjonen og dens instruks viser skjøteformularet og unders $\emptyset$ kte skjøter utstedt i medhold av res. post 8 hva som fant sted. I formularet nyttes formen «Gaard-Pladsen [...] anført i Jord-Inddelings-Forretningen [er] afhjemlet til hans [skjøtemottakerens] og hans rette og lovlige Arvingers fulde Eiendom». Dette peker på at det ikke skulle finne sted overføring av eiendomsrett, noe som i alminnelighet er et skjøtes funksjon, men på at delhaveren (i fellesskapet) fikk beskrevet, registrert og tinglyst sin del av fellesskapet som egen eiendom. Amtmann Fieldsted, som var resolusjonens «far», utstedte skjøtene nøyaktig slik det var forutsatt i skjøteformularet i perioden han forvaltet jordinndelingen (1776-1778). Selv om de etterfølgende amtmennene Heiberg og Sommerfelt ikke var like tro mot formularets ordlyd og nyttet formuleringen «overdraget til», er det intet som tyder på at de utstedte skjøter med annet materielt innhold enn det Fieldsted gjorde.

Fra ca. 1790 overtok sorenskriverne jordinndelingene, som inntil da var utført av to kgl. oppnevnte landmålere, nå med betegnelsen skyldsatningsforretning. Det er imidlertid intet som tyder på at disse forretningene materielt sett skilte seg fra de tidligere. Det er det heller ikke for forretningene amtmann Martin A. Unmack utstedte skjøte for i 1803-1804, noe som er av interesse sett i lys av hans innberetning i 1803 om utskifting (se punkt 3.4). Det for øvrig også påvist ytterligere utskiftingselementer i skjøtene, slik som ordning av felles bruk og årkast i en forretning fra 1814. For $\emptyset v$ rig må det vektlegges at til grunn for studien er det unders $\varnothing \mathrm{kt}$ et forholdsvis stort antall skjøter (40 stk.), hvor det synliggjøres en entydig praksis.

Flytter vi oss fram til 1826, synes Commissionen til Finmarkens Opkomst å være oppsatt på at utskiftingen påbegynt med hjemmel i 1775-resolusjonen skulle fortsette. Det synliggjøres av at den foreslo en egen utskiftningslov, hvor hovedregelen skulle være utskifting utført av en kommisjon satt sammen av distriktets sorenskriver og landmåler, bekostet av det offentlige.

Oppfatningen om statens eiendomsrett, nærmest på et privatrettslig grunnlag, kommer første gang til syne hos nevnte kommisjon. Den ble sterkere uttrykt drøye to tiår senere ${ }^{101}$ for så å bli lovfestet 22. juni 1863 i lov om Afhændelse av Statens Jord i Finmarkens Landdistrict. Så vel behovet for utskifting som historien om det som hadde foregått i medhold av 1775resolusjonen, svant da raskt hen i et historiens tåkeslør, ${ }^{102}$ slik at historien har blitt til at de første utskiftingene i Finnmark ble påbegynt i 1938. Det har vært historien fram til i dag.

Det er som nevnt ikke grunn til å betvile at det var jorddelinger som fant sted med hjemmel i 1775-resolusjonen. Det kan selvfølgelig drøftes hvor reelle de var, sett ut ifra at inndelingene

\footnotetext{
101 Steinar Pedersen, «Fra bruk av naturgodene etter samiske sedvaner til forbud mot salg til ikke-norsktalende», NOU 2001: 34 Samiske sedvaner og rettsoppfatninger, s. 291-381 (s. 318-320).

102 Selv om lov 24. april 1869 om Ordning af Jordforholdene i Finmarkens Amt hadde en begrenset hjemmel til frivillig utskifting i § 1 (c), er det knapt nok eksempler på at hjemmelen er nyttet.
} 
Jordinndelingene i Finnmark: var de Norges eldste offentlige utskiftinger?

i all hovedsak omfattet allerede etablerte boplasser (men med uavklarte grenser og utstrekning m.m.). Det kan følgelig også drøftes om betegnelsen utskifting (eller jordskifte) med dagens begrep er dekkende, eller om man i dag heller ville betegne mye av det som ble utført, som rettsutgreiing eller grensefastsetting. Framfor å la dette bli en drøfting av begreper, som nødvendigvis ikke var like presise på slutten av 1700-tallet som i dag, er det etter mitt skjønn naturlig å legge vekt på oppfatningene til de som i samtiden sto nærmest det som skjedde, og da kan det foruten amtmann Fieldsted, vises til amtmann Unmack. Han var i 1803 ikke i tvil om at «Udskifting i senere Tiid er [...] udført ved Sorenskriver og Mænd». At sorenskrivere erstattet landmålere og selv deltok i markarbeidet, tyder også på at det som fant sted var mer enn enkle grensefastsettinger. Når Tønnesen i 1972 skriver at «[d]et man således har for seg, er intet mindre enn en gigantisk utskiftning mellom Kongen, den enkelte bygdemann og bygdelagene», ${ }^{103}$ var han trolig nærmere sannheten enn han var klar over.

Det må etter dette kunne konkluderes med at det ble utført et stort antall utskiftinger eller utskiftingsliknende forretninger i Finnmark i perioden 1776-1815. Det kan også legges til grunn at de er blant de eldste i offentlig regi i Norge. De er likevel ikke de eldste; selv om Norge fikk sin første utskiftningslov i 1821, utførte sorenskriver Poul Schonevig et stort antall utskiftningsforretninger i Nordfjord i tidligere Sogn og Fjordane fylke i første halvdel av 1700tallet. ${ }^{104}$ Rammene for denne artikkelen har ikke muliggjort studier av Schonevigs arbeider eller sammenlikning av disse med dem landmålere og sorenskrivere utførte i Finnmark.

Sett i et samfunnsøkonomisk perspektiv, og i forhold til befolkningstall, var det som fant sted i Finnmark, en jordreform neppe mindre omfattende enn den samtidige i Danmark. Lengst nord i helstaten bidro ikke reformen til å avvikle stavnsbånd og leilendingsvesen, men til at eiendommer ble delt fra et udefinert fellesskap, oppmålt, beskrevet og matrikulert, slik at eierne kunne vite grensene for sine eiendommer, forbedre sitt jordbruk, bli bofaste samt bruke eiendommene som sikkerhet for kreditt og investeringer. For Kongen og Rentekammeret $\mathrm{i}$ København bidro jordinndelingen og matrikuleringen ganske sikkert til et mer veldrevet jordbruk, $\varnothing \mathrm{kt}$ handel, «Folkeformerelse» og dermed et mer velfungerende næringsliv og bedre grunnlag for skatteinnkreving.

\footnotetext{
${ }^{103}$ Tønnesen (1972), s. 146.

${ }^{104}$ Statsarkivet i Bergen, avskrift av Nordfjord sorenskriveris tingbok I. A. nr. 20 (1718-1720) fol. 27a, avskrift av Nordfjord sorenskriveris tingbok I. A. nr. 21 (1721-1723), fol. 186, avskrift av Nordfjord sorenskriveris tingbok A nr. 27 (1726-1728) fol. 4, fol. 52, avskrift av Nordfjord sorenskriveris tingbok A. nr. 31 (1735-1738) fol. 55a, 140a-143a (velvillig tilsendt av statsarkivar Yngve Nedrebø). Rentekammerets sirkulær fra 1803, jf. Juvkam (1917) s. 50-52, viser dessuten at det var utført utskiftinger av «Sorenskriver og Mænd» i Aggershuus og Christiansands Stift.
} 
Jordinndelingene i Finnmark: var de Norges eldste offentlige utskiftinger?

\section{Referanser}

\section{Litteratur $\mathrm{mm}$.}

Bergh, Trond og Tore J. Hanisch, Vitenskap og politikk: Linjer i norsk sosialøkonomi gjennom 150 år, Oslo 1984.

Bing, Lars Hess, Beskrivelse over Kongeriget Norge, Øerne Island og Farøerne, samt Grønland, Kiøbenhavn 1796.

Bjørn, Claus og Ove W. Dietrich, «Det Kongelige Danske Landhusholdningsselskab», Den Store Danske, https://denstoredanske.lex.dk/Det_Kongelige Danske_Landhusholdningsselskab (2009) (02.01.21)

Borgedal, Paul, «Jordeiendommenes historie i Norge» i Torleif Grendahl (red.), Jordskifteverket gjennom 100 år 1859-1958, Oslo 1959.

Brandt, Fr., Tingsretten fremstillet efter den norske Lovgivning, Christiania 1867.

Brækhus, Sjur og Axel Hæren, Norsk tingsrett, Oslo 1964.

Danmarkshistorien, «Landboreformer i slutningen af 1700-tallet», Aarhus universitet, https://danmarkshistorien.dk/leksikon-og-kilder/vis/materiale/landboreformer/ (02.01.21).

Danmarkshistorien, «Rentekammeret», Aarhus universitet, https://danmarkshistorien.dk/leksikon-ogkilder/vis/materiale/rentekammeret/ (02.01.21).

Det Kongelige Danske Landhusholdningsselskab, https://1769.dk/about/historie (02.01.21).

Grendahl, Torleif, Jordskifteverket gjennom 100 år, Oslo 1959.

Haffner, Vilhelm, Innstillinger og betenkninger fra kongelige og parlamentariske kommisjoner, departementale komiteer m.m. 1814-1924, Oslo 1925.

Holm, Edvard, Danmark-Norges historie fra Den Store Nordiske Krigs Slutning til Rigernes Adskillelse (1790-1814), sjette bind, anden del, Kjøbenhavn 1909.

Jebens, Otto, Om eiendomsretten til grunnen i Indre Finnmark, Oslo 1999.

Juvkam, O., «Træk fra utskifningsvæsenets historie», Tidsskrift for Det norske Utdskiftningsvaesen, 1917, s. 41-161.

Juvkam, O., «Utstykking og skyldsetting i Finnmark», Tidsskrift for Det norske Utskiftingsvesen, 1948, s. $127-141$.

Kraft, Jens, Topografisk-Statistisk Beskrivelse over Kongeriget Norge, Sjette Deel, Det Nordenfjeldske Norge, Anden Deel, Christiania 1835.

Langnes, Mads, «Det fordervelege jordfellesskapet», Heimen 4/2019, s. 279-295.

Meinich Olsen, K., Norsk almenningsret, Oslo 1928.

Paus, Hans, Naturens Ret, Som en Grundvold til den Danske og Norske Borgerlige Ret, del 2, Kjøbenhavn 1750.

Paus, Hans, Sorenskriver Hans Paus' Indberetning av 1769 om Finmarkens фkonomiske tilstand, Vads $\varnothing 1908$.

Pedersen, Steinar «Fra bruk av naturgodene etter samisk sedvaner til forbud mot salg til ikke-norsktalende», NOU 2001: 34 Samiske sedvaner og rettsoppfatninger, s. 291-381.

Rathke, Jens, Afhandling om de norske fiskerier og beretninger om reiser i aarene 1795-1802 for at studere fiskeriforhold m.v., Bergen 1907. 
Jordinndelingene i Finnmark: var de Norges eldste offentlige utskiftinger?

Ravna, Øyvind, «Nye bidrag til eiendomshistorien i Finnmark», Heimen nr. 1/2017, s. 6-27.

Ravna, Øyvind, «Den tidligere umatrikulerte grunnen i Finnmark: Jordfellesskap fremfor statlig eiendom?», Tidsskrift for Rettsvitenskap nr. 2-3/2020, s. 219-263.

Robberstad, Knut, «Kløyvd eiendomsrett», Lov og Rett 1963, s. 162-166.

Sandvik, Gudmund «Europeisk rettshistorie i mellomalderen. Førelesningar», Jussens venner, 6-7/1989, s. 201-309.

Sandvik, Gudmund, «Statens grunn i Finnmark. Et historisk perspektiv» i NOU 1993: 34 s. 334-380.

Scheel, Herman, Forelaesninger over norsk Tingsret, Kristiania 1912.

Schiefloe, Asm., Hovedlinjer i Norsk almenningsrett, Oslo 1955.

Schou Jacob Henric, Chronologisk Register over de Kongelige Forordninger og Aabne Breve, som fra Aar 1670 af ere udkomne, VIII Deel fra 1781 til 1784, Kiøbenhavn 1795.

Schlegel, Joh. Fredrik Wilhelm, Statistisk Beskrivelse af de fornemste europaiske Stater, Første Deel, Kiøbenhavn 1793.

Schnitler, Peter, Major Peter Schnitlers grenseeksaminasjonsprotokoller 1742- 1745, bind 3 ved Lars Ivar Hansen og Tom Schmidt, Norsk historisk kjeldeskrift-institutt, Oslo 1985.

Sevatdal, Hans, ved Per Kåre Sky og Erling Berge, Eigedomshistorie. Hovudliner i norsk eigedomshistorie frå 1600-talet fram mot nåtida, Oslo 2017.

Sommerfelt, Ole Hannibal, «Kort Beskrivelse over Finmarken», Topografisk Journal for Norge, bind 7 (24), 1799, s. 101-179.

Spilling, Knut, Av Finmarkens skogret, Bilag til Norsk Retstidende no. 4-6, Kristiania 1920(b).

Steinsholt, Håvard, «Oreigning», Hans Sevatdal, ved Per Kåre Sky og Erling Berge, Eigedomshistorie.

Hovudliner i norsk eigedomshistorie frå 1600-talet fram mot nåtida, Oslo 2017, s. 376-382.

Trøan, Simon, «Om kongelig resolusjon av 08.06.1775 og transkripsjon av promemoria av 31.03.1775», Riksarkivet, brev, 13.12.2019, ref. 2019/22285.

Tønnesen, Sverre, Retten til jorden i Finnmark. Rettsreglene om den såkalte «Statens umatrikulerte grunn»en undersøkelse med sarlig sikte på samenes rettigheter, Bergen 1972.

Wessel-Berg, Fr. Aug., Kongelige Rescripter, Resolutioner og Collegial-Breve for Norge i Tidsrummet 1660-1813, Andet Bind 1746-1780, Christiania 1842.

\section{Lover, forarbeider, utredninger og andre offentlige dokumenter}

Fieldsted, Thorkel, promemoria 31.03.1775, i arkiv Riksarkivet/EA-3111 Rentekammeret,

Kammerkanselliet, serie Gfd - Dokumenter til forestillinger, pakke 22 (1772-1775), mappe: N. res. 24/1775 (8/6), 1775 nr. 24, Finnmark vedk.

Finnmarkskommisjonen, Rapport Felt 4 Karasjok, bind 1, 2019.

Forestilling no. 24, Riksarkivet, Rentekammeret, Kammerkanselliet, G/Gf/Gfa/L0057: Norsk relasjons- og resolusjonsprotokoll (merket RK 52.57), 1775, https://media.digitalarkivet.no/view/60313/106 (20.10.21). Forhandlings Protocol Commissionen der er nedsatt for at foretage Undersøkelser om Midlerne til Finmarkens Opkomst 1826, http://xml.arkivverket.no/diverse/forhandprotfinnmarkkomm1824-30.pdf (20.10.21). 
Jordinndelingene i Finnmark: var de Norges eldste offentlige utskiftinger?

Forordning 23 April 1781 om Jord-Fælledsskabets Ophævelse med flere foranstaltninger til Landvæsenets Forbedring i Danmark, i Schou (1795 [se ovenfor]), s. 96-133.

Forslag til landmålerinstruks, i Tønnesen (1972), s. 392-397 med referanse kgl. Resolusjoner, nr. 12, 8. juni 1775, Rentekammeret, 1. Nordenfjeldske kontor 1775-77.

Innstilling om lov og forskrifter om Statens umatrikulerte grunn i Finnmark fylke, 1962.

Kong Christian Den Femtis Norske Lov (NL) av 15. april 1687.

Kongelig Resolution 27. mai 1775 [8. juni 1775] ang. Jorddelingen i Finmarken samt Bopladses Udvisning og Skyldlægning sammesteds, https://lovdata.no/dokument/NL/lov/1775-05-27 (21.01.21). Se også WesselBerg (1842 [se ovenfor]), s. 623-625.

Landmålerprotokoll (for Finmarken) 1776-1845, SATØ, https://media.digitalarkivet.no/view/39721(21.02.21).

Lov 17. August 1821 angaaende Jord og Skovs Udskiftning av Fællesskab.

Lov 12. oktober 1857 om Udskiftning av Jord og Skovs Fællesskab.

Lov 24. april 1869 om Ordning af Jordforholdene i Finmarkens Amt.

Lov 22. desember 1950 om jordskifte o.a.

Kopibok nr. 6 (1772-1773) for Finmarkens amt, fol. 4 og fol. 103-104 (brev til Rentekammeret, hhv. 9. aug. 1772 og 28. sept. 1773), Statsarkivet i Troms $\varnothing$.

Pantebok nr. 1 (1776-1794), Sorenskriveren i Finnmark, Statsarkivet i Troms $\varnothing$ (samtlige pantebøker finnes scannet her: https://media.digitalarkivet.no/tl/pbok/browse (19.12.20)).

Pantebok nr. 2 (1794-1813), Sorenskriveren i Finnmark.

Pantebok nr. 3 (1813-1831), Vest-Finnmark sorenskriveri.

Pantebok nr. 1 (1817-1862) for Tana sorenskriverembete.

Justitsprotokol for Finmarkens sorenskriveri 1813-1822, aut. 27 febr. (hentet fra Finnmarkskommisjonen). Statsarkivet i Bergen: Nordfjord sorenskriveris tingbok I. A. nr. 20 (1718-1720), nr. 21 (1721-1723), nr. 27 (1726-1728) og nr. 31 (1735-1738). 